\title{
Tyrosine Nitration of IkBa: A Novel Mechanism for NF-кB
}

\section{Activation}

\author{
Vasily A. Yakovlev ${ }^{\dagger}$, Igor J. Barani ${ }^{\dagger}$, Christopher S. Rabender $^{\dagger}$, Stephen M. Black ${ }^{\ddagger}$, J. Kevin \\ Leach $\S$, Paul R. Graves ${ }^{\dagger}$, Glen E. Kellogg $\dagger^{\dagger}$, and Ross B. Mikkelsen ${ }^{\dagger}{ }^{*}$ \\ $\dagger$ Department of Radiation Oncology, Massey Cancer Center, Virginia Commonwealth University, Richmond \\ VA 23298 \\ \$Vascular Biology Center, Medical College of Georgia, Augusta, GA 30912 \\ $\dagger \dagger$ Department of Medicinal Chemistry, Virginia Commonwealth University, Richmond, VA23298 \\ $\S$ Drug Metabolism and Pharmacokinetics, Merck Research Laboratories, Boston, MA 02115.
}

\section{Abstract}

The NF- $\mathrm{KB}$ family of transcription factors is an important component of stress-activated cytoprotective signal transduction pathways. Previous studies demonstrated that some activation mechanisms require phosphorylation, ubiquitination and degradation of the inhibitor protein, IкB $\alpha$. Herein, it is demonstrated that ionizing radiation in the therapeutic dose range stimulates NF- $\mathrm{BB}$ activity by a mechanism in which I $\kappa \mathrm{B} \alpha$ tyrosine- 181 is nitrated as a consequence of constitutive $\mathrm{NO}^{\bullet}$ synthase activation, leading to dissociation of intact I $\mathrm{B} \alpha \alpha$ from NF- $\kappa \mathrm{B}$. This mechanism does

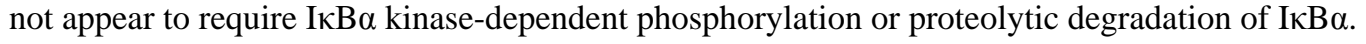
Tyrosine-181 is involved in several noncovalent interactions with the p50 subunit of NF- $\mathrm{KB}$

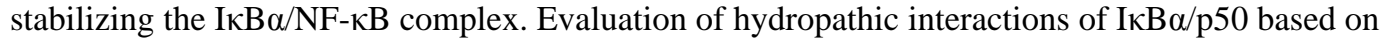
the crystal structure of the complex is consistent with nitration disrupting these interactions, and dissociating the I $\mathrm{KB} \alpha / \mathrm{NF}-\kappa \mathrm{B}$ complex. Tyrosine nitration is not commonly studied in the context of signal transduction. However the present results indicate that tyrosine nitration is an important posttranslational regulatory modification for NF- $\mathrm{kB}$ activation and possibly for other signaling molecules modulated by mild and transient oxidative and nitrosative stresses.

The Rel/NF- $\mathrm{BB}$ family of transcription factors mediate cellular responses to oxidative and other stresses (1). NF- $\kappa B$ transcription factors are formed by the homo-or heterodimerization of proteins of the Rel family including p50, p52, p65 (RelA), c-Rel and RelB. The most abundant and best-understood dimer is p65/p50. This dimer exists in the cytoplasm complexed with an

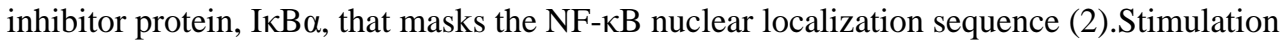
of cells with cytokines such as tumor necrosis factor (TNF $\alpha$ ) results in the phosphorylation, ubiquitination and degradation of IкB $\alpha$, permitting the unmasked $\mathrm{p} 65 / \mathrm{p} 50$ heterodimer to translocate into the nucleus (2).

Ionizing radiation (IR) also activates NF-kB by mechanisms not fully understood. At high IR doses (>10Gy) activation appears similar to that observed for TNF $\alpha$. DNA damage-inducible

*To whom correspondence should be addressed: Ross B. Mikkelsen, Department of Radiation Oncology, Massey Cancer Center, 401 College St., Richmond, VA 23298, Tel.: (804) 628-0857; Fax: (804) 828-6042; E-Mail: E-mail: rmikkels@ vcu.edu.

Research was supported by National Institutes of Health Grants, CA65896, CA72955, CA89055 (RBM) and HD39110 and HL070061 (SMB) and an ASTRO Resident Research Grant (IJB). We thank Dr. Neal Scarsdale for the ${ }^{13} \mathrm{C}$ NMR studies.

Research Collaboratory for Structural Bioinformatics Protein Databank = PDB \# 1IKN; Research Collaboratory for Structural Bioinformatics Protein Databank = PDB \# 1NFI. 
kinases, ATM and DNA-PK, activate IאB $\alpha$ kinases (e.g., IKK $\beta$ ) stimulating the phosphorylation, ubiquitination and proteasome degradation of $\operatorname{I\kappa B} \alpha(1,3)$. IKK $\beta$ activity and

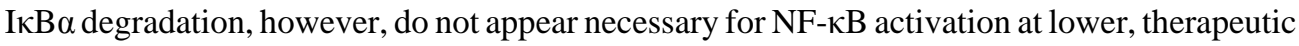
doses of IR, e.g. (4,5). Indeed, IR inhibits proteasomal activities at doses as low as $0.2 \mathrm{~Gy}$ with maximal inhibition at $2 \mathrm{~Gy}(4,6)$. IKK $\beta$ has other functions including phosphorylation of S536 in the transactivation domain of the p65 subunit (7-10). Serine-536 phosphorylation is independent of I $\mathrm{\kappa} \mathrm{B} \alpha$ phosphorylation and important for enhancing $\mathrm{p} 65$ transactivation potential and modulating gene target selection.

Recent studies demonstrate that $\mathrm{NO}^{\bullet}$ and a metabolic derivative, peroxynitrite $\left(\mathrm{ONOO}^{-}\right)$ modulate NF- $\mathrm{KB}$ activity (11-15). For example, addition of a $\mathrm{ONOO}^{-}$donor to cultured cells stimulates NF- $\kappa \mathrm{B}$ reporter activity without $\mathrm{I} \kappa \mathrm{B} \alpha$ degradation (11). These findings and the evidence that a $\mathrm{Ca}^{2+}$ dependent constitutive $\mathrm{NO}^{*}$ synthase activity in epithelial cells is transiently stimulated by low IR doses (16-19) prompted the following investigation of NO* signaling in IR-induced activation of NF- $\mathrm{KB}$.

\section{Materials and Methods}

\section{Cell Culture, Irradiation, and Transfection}

CHO-K1 and MCF-7 cells were cultured and irradiated at a dose rate of $2 \mathrm{~Gy} / \mathrm{min}$ with a ${ }^{60} \mathrm{Co}$ source as previously described (18). Cells were transfected with the LipofectAMINE PLUS ${ }^{\mathrm{TM}}$ kit (Invitrogen).

\section{Reagents}

Primary antibodies used: actin, nuclear lamin A/C, I $\kappa \mathrm{B} \alpha$, NOS1, IKK $\beta$ and p65 (Santa Cruz Biotechnology); nitro-tyrosine (Upstate Biotechnology); p50, phospho-S32/36-IкB $\alpha$, and 9E10 epitope of c-Myc (Cell Signaling).

Wild type pCMV-IкB $\alpha$ from Clontech has two ATG start sites with the second having an optimal Kozak sequence. For this reason an IкB $\alpha$ doublet was detected after SDS polyacrylamide gel electrophoresis in early experimentation. Both proteins were, however, equally nitrated (e.g. Fig. 2A,E; 4A). Amino acid substitution mutants were constructed from pairs of point mutation primers by PCR technology with wild type $\mathrm{pCMV-I \kappa B} \alpha$ as the initial template. Mutations were verified by full-length sequencing. Another set of mutants was prepared with an $\mathrm{N}$-terminal c-Myc epitope tag to facilitate analysis.

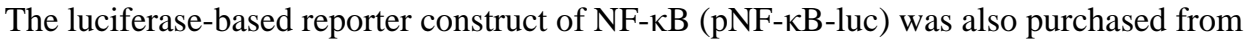
Clontech. Luciferase activity was measured in cell lysates $24 \mathrm{hr}$ after IR exposure with a Luciferase Reporter Gene Assay Kit (Packard Bioscience) according to the manufacturer's directions.

The human shRNA IKK $\beta$ plasmid was provided by Upstate Biotechnology. The dominant negative NOS-1 mutant (HemeRedF) and its effects on expression and activity of NOS-1 in CHO and other cells have been described (17,20,21). Mouse NOS-1 siRNAs and All Stars Negative Control siRNA were purchased from QIAGEN. HiPerFect Transfection Reagent (QIAGEN) was used for transfection of CHO-cells with siRNAs. Cells were seeded and transfected on the same day according to the manufacturer's reverse transfection protocol.

\section{Measurement of Nuclear NF-kB DNA Binding Activity}

CHO-cells were seeded $48 \mathrm{~h}$ before radiation in 100-mm dishes and transfected the same day with the NOS1 siRNAs or $24 \mathrm{~h}$ later with a plasmid expressing the HemeRedF NOS-1 mutant. Incubation with 100nM L-NNA was performed $4 \mathrm{~h}$ before radiation. NF- $\mathrm{kB}$ DNA binding 
activity in nuclear extracts prepared as in (22) was measured with a NF- $\kappa B$ p65 ELISA Kit (Stressgen Bioreagents) according to manufacturer's recommendations.

\section{Biochemical Analyses}

Immunoprecipitation and Western blotting methods have been described (17) (20). Protein detection was by chemiluminescence with alkaline phosphatase-conjugated secondary antibodies or with secondary antibodies conjugated with infrared fluorescent dyes and imaging with the Odyssey® Infrared Imaging System (Li-Cor ${ }^{\circledR}$ Biosciences). Cellular NOS activity was measured with an arginine to citrulline assay as previously described $(17,20)$.

\section{Mass Spectrometry}

All proteins were resolved by one-dimensional SDS-PAGE and silver stained. After destaining, proteins were in-gel digested with modified porcine trypsin $(0.6 \mu \mathrm{g}$, Promega) alone or with S. aureus V8 protease $(0.6 \mu \mathrm{g}$, Sigma Chemical Co.) for $12 \mathrm{hrs}$ according to the method of Shevchenko (23). The resultant peptides were purified with Poros $20 \mathrm{R} 2$ reverse phase packing (Applied Biosystems) and subjected to direct infusion nanospray using NanoES spray capillaries (PROXEON, Odense, Denmark) on an Applied Biosystems QSTAR® pulsar XL mass spectrometer. MS spectra were collected in positive mode with an ion spray voltage of 800 volts. Subsequent MS/MS spectra were collected and amino acid sequences obtained using BioAnalyst software.

\section{Structural Analysis}

To determine the optimal geometry of nitro-tyrosine, we performed quantum mechanical calculations using density functional theory with 6-311+G(d,p) basis set, B3PW91 hybrid functionals, default spin configuration, and net molecular charge of zero (24). Self-consistent field was calculated directly with convergence limit of $2 \times 10^{-5}$. These parameters ensured that optimized structure of nitro-tyrosine was available for calculation of its various structural and chemical properties. The force constants for bonds, bond angles, and dihedrals were calculated using the Hessian matrix. Subsequently, charge distribution and electronic polarizability of nitro-tyrosine were calculated in water solution to fully characterize the properties of this modified amino acid. These properties were properly entered in the CHARMM22 (25) parameter and topology files for use in NAMD2, a molecular dynamics algorithm $(26,27)$. The validity of quantum mechanical calculations was established by ${ }^{13} \mathrm{CNMR}$ spectroscopy using commercially available 3-nitro-tyrosine ethyl ester in $\mathrm{D}_{2} \mathrm{O}$ (see supplemental data).

Two X-ray structures of IкB $\alpha / \mathrm{NF}-\kappa \mathrm{B}$ complex are found in the Protein Data Bank - 1NFI (2.7 ̊ resolution) (28) and $1 \mathrm{IKN}$ ( 2.3 Å resolution) (29). The R-values for both structures were 0.223 . The sequence enumerations are identical for IKB $\alpha$ and $\mathrm{p} 65$ but are shifted by 3 residues for the p50 subunit. The 1IKN structure was used for our analysis. Energy minimization was performed for 2500 steps enabling energetic relaxation of the system.

For the HINT calculations, the PDB coordinates of control and nitrated I $\mathrm{B} \alpha / \mathrm{NF}-\kappa \mathrm{B}$ complexes at the end of minimization were used. We defined $\mathrm{Y} 181$ or nitro-Y181 as structure "A" and the remainder of the I $\mathrm{KB} \alpha / \mathrm{NF}-\kappa \mathrm{B}$ complex as structure "B". The HINT program was then used to evaluate a comprehensive set of non-bonded interactions between structures " $\mathrm{A}$ " and "B" (hydrogen bonding, acid-base, hydrophobic-hydrophobic, acid-acid, base-base, and hydrophobic-polar) (30-35). 


\section{Results}

\section{Inhibiting NOS-1 blocks IR-stimulated NF-KB activity}

Initial experiments tested whether radiation induced NOS-1 activity contributed to an increase of NF- $\mathrm{\kappa B}$ promoter activity measured with a luciferase based reporter assay. $\mathrm{CHO}$ cells were co-transfected with the reporter plasmid and either an empty vector or the dominant negative mutant of NOS-1 (HemeRedF) whose expression was previously shown to inhibit IR-activated NOS activity in CHO cells $(17,20)$. A single IR exposure of 5 Gy stimulated a $1.5-3$ fold increase in NF- $\kappa B$ dependent luciferase activity measured at $24 \mathrm{~h}$ post-IR (e.g. Fig. 1A,B,G; $2 \mathrm{G})$. This increase in activity was similar to what others have observed with diverse cell types after an exposure to IR (36-38). Expression of HemeRedF completely inhibited IR-stimulated reporter gene expression and reduced basal reporter activity by 40 to $50 \%$ (Fig. 1A). The effect of genetically inhibiting NOS-1 activity on NF- $\mathrm{KB}$ promoter activity was confirmed pharmacologically with the NOS inhibitor, $\mathrm{N}^{\mathrm{G}}$-Nitro-L-arginine (L-NNA). Incubating cells with L-NNA $4 \mathrm{hr}$ prior to radiation significantly reduced both basal and IR-induced NF- $\mathrm{KB}$ promoter activity (Fig. 1B,G; 2G).

To further validate the role for NOS-1 in NF- $\mathrm{kB}$ activation by IR, cells were transfected with control and siRNA directed against NOS-1. The inset of Figure 1C demonstrates that both siRNAs tested were efficient in knocking down expression of NOS- 1 in CHO cells. We compared the relative effects of siRNA transfection, expression of the NOS-1 mutant, HemeRedF, and the chemical inhibitor, L-NNA, with respect to their relative abilities to inhibit

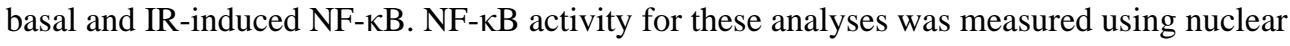
extracts in an ELISA assay for $\mathrm{p} 65$ binding to a NF- $\kappa \mathrm{B}$ specific oligonucleotide consensus sequence. Results in Figure 1C show that all three methods of inhibiting NOS-1 activity were effective at blocking IR-stimulated NF- $\kappa$ B activity although the molecular approaches appeared more effective. Further validation was obtained by following nuclear translocation of p65 subsequent to radiation. As shown in Fig. S3 of Supplemental Data, nuclear isolates were probed for $\mathrm{p} 65$ by Western blot analysis normalized with respect to nuclear lamin levels. Nuclear accumulation of p65 increased within $10 \mathrm{~min}$ of irradiation by a mechanism inhibited by L-NNA.

\section{Activation of NF-kB by a low IR dose does not stimulate IKBa phosphorylation}

We tested whether low IR doses activated IKK measured as IKB $\alpha$ S32/36 phosphorylation and proteolysis. By this assay, IKK activity was not stimulated at the IR doses used ( $\leq 5 \mathrm{~Gy}$ ) (Fig. 1D). Control experiments with TNF $\alpha$ stimulation showed enhanced, but transient IкB $\alpha$ Ser32/36 phosphorylation and progressive decrease in I $\kappa \mathrm{B} \alpha$ protein levels indicating that this IKK-dependent activation mechanism was intact. Incubation with L-NNA or expression of

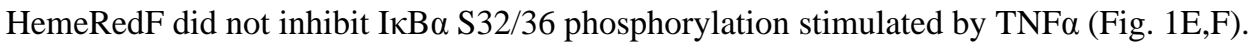

NF- $\kappa \mathrm{B}$ activation by TNFא or IR at 5 Gy were also compared in cells transfected with shRNA specific to IKK $\beta$ to abrogate this activation pathway for NF-KB (Fig. 1G). A co-transfected luciferase reporter construct was used to assess cellular NF- $\mathrm{KB}$ activity. Cells expressing shRNA showed IKK $\beta$ protein levels less then $10 \%$ of control cells, transfected with empty vector. This inhibition of IKK $\beta$ expression with shRNA reduced NF- $\mathrm{KB}$ basal activity by $50 \%$ and completely blocked stimulation by TNF $\alpha$. In contrast to these observations with TNF $\alpha$, IR-stimulated NF- $\mathrm{kB}$ activity was only reduced by approximately $50 \%$ with IKK $\beta$ shRNA expression. The remaining activity was inhibited by treatment with L-NNA (Fig. 1G). Since both basal and IR-stimulated NF-KB activities were reduced by IKK $\beta$ shRNA expression, the fold-activation with IR achieved in these cells was not significantly different from that of control, IKK $\beta$-expressing cells. 


\section{Radiation stimulates the tyrosine nitration of IKBa}

IR-activation of NOS stimulates $\mathrm{ONOO}^{-}$generation detected as tyrosine nitration of a number of proteins (17). We tested whether IR at 5 Gy stimulated the nitration of I $\mathrm{B} \alpha$ using CHO cells transfected with human wild type IкB $\alpha$. Anti-nitro-tyrosine immunoprecipitates from lysates of control and irradiated cells were analyzed by Western blot for IאB $\alpha$ (Fig. 2A). IR stimulated oscillating changes in IкB $\alpha$ tyrosine nitration with an initial maximum at 10-20 min post-IR and a second maximum at $\approx 40 \mathrm{~min}$. Similar results were obtained with endogenous I $\mathrm{B} \alpha$ in MCF-7 breast carcinoma cells (Fig. 2B). The reciprocal experiment with immunoprecipitation of I $\mathrm{B} \alpha \alpha$ followed by blotting with anti-nitro-tyrosine $\operatorname{IgG}$ showed the same oscillations in tyrosine nitration of I $\kappa \mathrm{B} \alpha$ without changes in I $\mathrm{B} \alpha$ protein expression

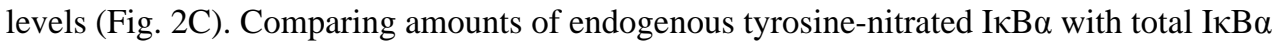
suggests that up to $25 \%$ is transiently nitrated 15 min post-IR (Fig. 2D). Basal and IR-induced

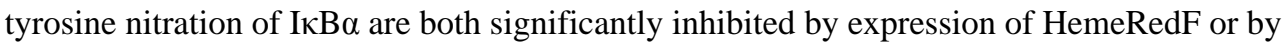
incubating cells with L-NNA (Fig. 2E).

Previous studies demonstrated oscillations of NF- $\kappa B$ DNA binding that correlated with oscillations in total I $\mathrm{B} \boldsymbol{\alpha} \alpha$ protein levels following TNF $\alpha$ treatment of cells $(39,40)$. The present work with low doses of IR, in contrast, showed no measurable change in total cellular IкB $\alpha$ levels after IR at 5 Gy (Fig. 2A,C,E). Thus, it is unlikely that selective proteolysis of nitrated I $\mathrm{B} \alpha$ accounts for the observed oscillations in I $\mathrm{B} \alpha$ nitration following an IR exposure. Proteolytic degradation of $\mathrm{I} \kappa \mathrm{B} \alpha$ is not a requirement for NF- $\kappa \mathrm{B}$ activation, e.g. $(11,41)$. Furthermore, IR inhibits proteasome activities $(4,6)$.

\section{Radiation dose response analyses comparing cellular NOS activity, IKBa tyrosine nitration and NF-KB transcription reporter activity}

Our previous studies $(17,18)$ using a fluorescent dye to measure reactive oxygen/nitrogen species demonstrated a dose response which saturated at doses $>6 \mathrm{~Gy}$. These findings were confirmed by measuring as a function of IR dose cellular NOS activity directly with an argininecitrulline conversion assay or indirectly by measuring tyrosine nitration of IאB $\alpha$ (Fig. 2F). Both measures of $\mathrm{NO}^{\bullet}$ activity progressively increased with IR dose and reached relative plateaus at doses greater than $6 \mathrm{~Gy}$. A similar dose response curve was observed for NF- $\mathrm{KB}$ reporter activity (Fig. 2G). At IR doses above 8 Gy, L-NNA was a less effective inhibitor of NF- $\kappa B$ activation. At 16 Gy or higher, inhibition of NOS-1 activity with LNNA had no effect on IRinduced NF- $\mathrm{kB}$ activity.

\section{Tyrosines 181 and 305 of IKBa are nitrated after irradiating intact cells}

A genetic approach was also used to determine sites of nitration. Each tyrosine of $I \kappa B \alpha$ was individually mutated to phenylalanine. $\mathrm{CHO}$ cells were transfected with plasmids expressing all 8 myc-tagged Y-F mutants and the myc tagged wild type I $\kappa B \alpha$. Tyrosine nitration of the mutants and wild type were compared as a function of time following an IR exposure of $5 \mathrm{~Gy}$ by immunoaffinity purification of the nitrated proteins followed by Western blot detection with anti-myc (Fig. 3). To facilitate comparisons between blots, each blot included one lane of wild type of myc-tagged IкB $\alpha$ obtained from cell lysates nitrated with $50 \mu \mathrm{M} \mathrm{ONOO}^{-}$and subsequently immunopurified with anti-nitro-tyrosine conjugated agarose beads. All single mutants demonstrated with approximately identical frequencies oscillating levels of nitrated I $\mathrm{B} \alpha$ following radiation. However, for the Y181F and Y305F single mutants, the amplitude in IR-induced nitration was significantly less than that observed for wild type and the other tyrosine mutants. A double mutant $(\mathrm{Y} 181 \mathrm{~F}+\mathrm{Y} 305 \mathrm{~F})$ was constructed to test whether these two tyrosines were exclusively nitrated following radiation. As shown in the bottom panels of Fig. 3 , the double mutant was not nitrated after a 5 Gy radiation exposure. 


\section{Peroxynitrite treatment of the NF-KB/IKBa nitrates tyrosines 181 and 305 of IKBa and dissociates the IKBa/NF-KB complex}

Initial experiments using the different $\mathrm{I} \kappa \mathrm{B} \alpha$ mutants and treatment of cell lysates with $\mathrm{ONOO}^{-}$also demonstrated a high degree of specificity in the $\mathrm{ONOO}^{-}$induced nitration of IкB $\alpha$. As observed with radiation only mutant proteins for tyrosines 181 and 305 showed significantly reduced nitration following a single bolus addition of $\mathrm{ONOO}^{-}$. The double mutant for these two tyrosines was not nitrated at all (Fig. 4A,B).

We attempted to validate the genetic evidence for $\mathrm{ONOO}^{-}$induced nitration of these two tyrosines by mass spectrometry. The cell lysate with overexpressed IкB $\alpha$ was nitrated with $\mathrm{ONOO}^{-}$and nitrated I $\mathrm{I} \mathrm{B} \alpha$ isolated by precipitation with anti-nitro-tyrosine $\mathrm{IgG}$, resolved by gel electrophoresis and processed for mass spectroscopy. After proteolysis, five I $\mathrm{KB} \alpha$ peptides were identified for coverage of $21 \%$ and this included 4 of the 8 tyrosines of IкB $\alpha$ (Table S1 of supplemental data). The tryptic peptide containing tyrosine- 181 is over 40 amino acids long and was not detected in the mass spectra. Attempts with different peptide cutting agents to obtain an identifiable peptide containing tyrosine-181 proved unsuccessful. However, a 20 amino acid peptide of IкB $\alpha$ (aa295-314) was sequenced and identified in the un-nitrated form and also as a peptide with a mass consistent with tyrosine nitration (+45Da, supplemental data, Fig. S1, S2). Our initial attempts to sequence the only tyrosine in this peptide, Y305, to confirm its nitration, have not been successful. Additional mass spectroscopic analysis of the IкB $\alpha 295$ 314 peptide indicated that $\mathrm{C} 308$ was modified by propionamide (an acrylamide adduct) indicating that $\mathrm{C} 308$ was not oxidized by the $\mathrm{ONOO}^{-}$treatment. Methionine-91 in the amino acid 88-95 peptide was also not oxidized. Both findings support the conclusion that a bolus $\mathrm{ONOO}^{-}$treatment is relatively specific in its effects on amino acid modification of $\mathrm{I} \kappa \mathrm{B} \alpha(42$, 43).

We tested whether in vitro nitration with exogenous $\mathrm{ONOO}^{-}$dissociated the I $\mathrm{B} \alpha / \mathrm{NF}-\kappa \mathrm{B}$ complex. A single bolus addition of $\mathrm{ONOO}^{-}$was used since the short half life of $\mathrm{ONOO}^{-}(<1$ sec) enhances specificity in its reactions, e.g. $(42,43)$. Cell lysates prepared under mild nondenaturing conditions were treated with 200 or $400 \mu \mathrm{M} \mathrm{ONOO}^{-}$. Two consecutive immunoprecipitations were performed. Agarose-conjugated anti-p65 IgG was used to pull down the NF- $\kappa \mathrm{B} / \mathrm{I} \kappa \mathrm{B} \alpha$ and free NF- $\kappa \mathrm{B}$ complexes. After centrifugation to remove these complexes, the resulting supernatants were incubated with agarose-conjugated anti-I $\operatorname{KB} \alpha \operatorname{IgG}$ to pull down free I $\kappa \mathrm{B} \alpha$. Western blots of the immunoprecipitates were probed with antibodies against $\mathrm{p} 65$, I $\kappa \mathrm{B} \alpha$ and nitro-tyrosine. With increasing concentrations of $\mathrm{ONOO}^{-}$, a decreasing amount of I $\mathrm{K} \mathrm{B} \alpha$ associated with p65 with a corresponding increase in free tyrosine-nitrated

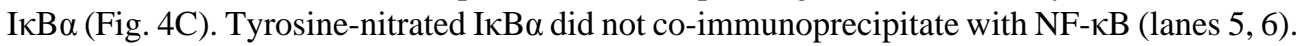
For long exposure times and at high $\left[\mathrm{ONOO}^{-}\right]$a broad smear of nitro-tyrosine staining was observed in p65 immunoprecipitates but with no distinct band for IкB $\alpha$ (lane 3). Neither p50 nor p65 were nitrated under these conditions (data is not shown) and the p50/p65 dimer remained intact as shown by co-immunoprecipitation (Fig. 4D). These results suggest that

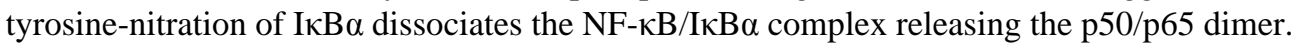

Cell lysates were prepared from cells transfected with myc-tagged wild type I $\mathrm{KB} \alpha$ and mutants (Y42F, Y181F and Y305F) and treated with $200 \mu \mathrm{M} \mathrm{ONOO}^{-}$. NF- $\mathrm{KB}$ immunoprecipitates obtained with anti-p65 were probed for $\mathrm{p} 65$ and myc-tagged I $\mathrm{I} B \alpha . \mathrm{ONOO}^{-}$treatment decreases the amount of $\mathrm{I} \kappa \mathrm{B} \alpha$ associated with $\mathrm{p} 65$ in wild type and all mutants tested except for the Y181F mutant (Fig. 4E). These results suggest that Y181 is critical to the stability of the NF-kB/ $\mathrm{I} \kappa \mathrm{B} \alpha$ complex following $\mathrm{ONOO}^{-}$treatment.

$\mathrm{CHO}$ cells were co-transfected with the NF- $\mathrm{KB}$ reporter gene and either myc-tagged wild type or the myc-tagged I $\kappa \mathrm{B} \alpha \mathrm{Y} \rightarrow \mathrm{F}$ mutants. As expected, over-expression of wild type or mutants inhibited basal NF- $\kappa B$ reporter activity $(\approx 90 \%)$. However, a significant IR-induced activation 
( 1.4) was still observed in cells expressing wild type or the Y42F and Y305F mutants (Fig. $4 \mathrm{~F})$. This is observed if promoter activity is expressed in terms of absolute values or as ratios of reporter activities of irradiated to control cells. In contrast, IR-stimulated NF- $\mathrm{KB}$ reporter activity was completely blocked in cells expressing the Y181F mutant, demonstrating an important role for Y181 in the mechanism for IR-induced activation of NF- $\kappa B$. Basal NF- $\kappa B$ activity of $\mathrm{Y} 181 \mathrm{~F}$ I $\kappa \mathrm{B} \alpha$-mutant expressing cells was moderately higher relative to the basal NF- $\kappa B$ activity of cells overexpressing wild type or the other I $\kappa B \alpha$ mutants (Fig. 4F). This is consistent with a previous analysis of different I $\kappa \mathrm{B} \alpha$ mutants showing that a Y181A mutant had a slightly lower affinity for p50/p65 (44). The variability in basal activity (e.g. Fig. 5A) probably reflects difference in expression levels.

Tyrosine-42 was also examined because previous reports indicated that its phosphorylation was important for oxidative activation of NF- $\kappa B$ without degradation of $\mathrm{I} \kappa \mathrm{B} \alpha(41,45)$. However, mutation of Y42 to phenylalanine was without effect on either the stability of the $\mathrm{NF}-\kappa \mathrm{B} / \mathrm{I} \kappa \mathrm{B} \alpha$ complex after $\mathrm{ONOO}^{-}$treatment (Fig. 4E) or IR-induced NF-B promoter activity (Fig. 4F).

\section{Mutation of tyrosine-181 blocks IR-but not TNFa induced NF-kB activity}

The effects of overexpressing wild type IKB $\alpha$ or the Y181F and S32A/S36A mutants of I $\kappa \mathrm{B} \alpha$ on IR and TNF $\alpha$ stimulated NF- $\mathrm{KB}$ activities were compared in MCF-7 cells. Serine-32 and -36 are phosphorylated by an IKK-dependent mechanism and thus the double mutant at these sites is a super-repressor for those activation mechanisms that proceed solely through IKK $(1,39)$. MCF-7 cells demonstrate a relatively weak NF- $\mathrm{kB}$ response to TNF $\alpha$ compared to other cell types reflecting the variable amount of TNF receptor in these cells (46).

Nonetheless the results in Figure 5 and in Fig. 1G demonstrate that as with other cell types, the TNF $\alpha$ response proceeds through a mechanism involving IKK and serines- 32 and 36 . The experimental results are presented in absolute amounts of reporter luciferase activity (Fig. 5A) or as ratios of treated versus control activities (Fig. 5B). Expression of the S32A/S36A double mutant was significantly more effective than wild type IKB $\alpha$ in suppressing TNF $\alpha$-stimulated $\mathrm{NF}-\kappa \mathrm{B}$ activity. The Y181F mutant and wild type I $\mathrm{B} \mathrm{B} \alpha$, in contrast, were no different in their effectiveness as inhibitors of TNF $\alpha$-stimulated NF- $\kappa B$ activity. Different results were obtained with IR as the activating mechanism. The Y181F mutant was significantly more effective at suppressing IR induced NF- $\mathrm{KB}$ activity but was without any super-repressor activity with $\mathrm{TNF} \alpha$ as the inducing agent. The results with the S32A/S36A mutant and IR parallel the findings provided above demonstrating that IR at the doses used here did not stimulate IкB $\alpha$ phosphorylation and degradation and that blocking expression of IKK with shRNA only partially inhibited IR stimulated NF-KB activation (Fig. 1G)

\section{A structural analysis of the effects of Y181 nitration on the IKBa/NF-KB complex}

The experimental results with IR and exogenous $\mathrm{ONOO}^{-}$coupled with the site-directed mutagenesis studies strongly support a mechanism of Y181 nitration in NF- $\mathrm{KB}$ activation by IR. Other oxidative modifications of I $\mathrm{I} B \alpha$ and nitration of either $\mathrm{p} 50$ or p65 after IR or $\mathrm{ONOO}^{-}$treatments were not detected. To further substantiate a role for Y181 nitration in IRinduced dissociation of the I $\kappa \mathrm{B} \alpha / \mathrm{NF}-\kappa \mathrm{B}$ complex an assessment of hydropathic interactions of Y181 with neighboring residues was made and molecular dynamics simulations were performed.

A computational chemistry program HINT (Hydropathic INTeractions) permits the quantitative analysis of all possible noncovalent atom-atom interactions including hydrogen bonding, coulombic, acid-base, and hydrophobic using the crystal structure of proteins (4749). HINT uses empirically derived constants based on thermodynamic hydropathy values from solvent partition measurements. The more positive the HINT value the more energetically 
favorable the change in free energy. HINT calculations have accurately estimated changes in free energy resulting from site-specific mutations and their effect on hemoglobin dimertetramer assembly $(48,49)$. Using HINT calculations, the interactions of Y181 or nitro-Y181 with the remainder of the NF- $\kappa \mathrm{B} / \mathrm{I} \kappa \mathrm{B} \alpha$ complex were compared on an atom-by-atom basis with an $8 \AA ̊$ cutoff.

The initial calculations required a quantum-mechanical comparison of the unmodified tyrosine residue with the nitrated form to generate topology files for tyrosine and nitro-tyrosine (Fig. S4, Supplemental data). These calculations demonstrated an altered side-chain electron distribution that accounts for the measured decrease in $\mathrm{pK}$ of the phenolic group from $\sim 10$ to $\sim 7(50,51)$. The portion of nitro-tyrosine containing the $\mathrm{NO}_{2}$ group was highly electronegative with the most electropositive portion localized over the $\mathrm{C}_{\alpha}$ and $\mathrm{C}_{\beta}$ atoms. This results in a dipole moment vector oriented almost parallel with the $\mathrm{C}_{\varepsilon}-\mathrm{NO}_{2}$ bond (Fig. S4, Supplemental Data). The magnitude of the calculated dipole moment of nitro-tyrosine was 5.78 Debye, compared with 3.63 Debye for tyrosine. Without nitration, the tyrosine dipole moment vector was oriented along the long axis of the side chain aligning the hydroxyl group of the phenol ring with $\mathrm{C}_{\beta}$ and $\mathrm{C}_{\alpha}$ atoms.

Crystallographic studies of the NF- $\kappa \mathrm{B} / \mathrm{I} \kappa \mathrm{B} \alpha$ complex show that I $\mathrm{B} \alpha$ is orientated such that fingers $3 / 4,4 / 5$, and $5 / 6$ of I $\mathrm{B} \alpha$ contact the p50 subunit $(28,29)$. Y181 and N182 extending from finger $3 / 4$ have multiple contacts with $\mathrm{p} 50$. Y181, in particular, has an important role in these interactions since it forms hydrogen bonds with p50 K252 and R258, $\pi$-stacks with Y351, and makes multiple van der Waals contacts with A260, P327, and L349. Table 1 shows results on an atom-by-atom basis of HINT calculations using a cut-off distance between atoms of 8 $\AA$. 'Nitration' of Y181 using the above generated topology file cause significant destabilizing changes in these interactions as seen by the net negative increase in total HINT score. A more instructive presentation of the HINT scores is shown in the Summary inset to Table 1 where

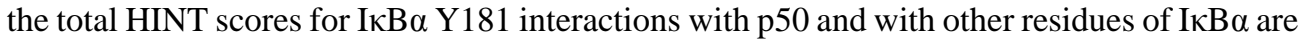
separated. Nitration results in a significant destabilization of p50-I $\mathrm{k} B \alpha$ interactions as indicated by a net negative increase in HINT score from -218 to -1970 . Assuming approximately $1 \mathrm{kcal} /$ mole per $500 \mathrm{HINT}$, this represents a change in free energy of approximately $3 \mathrm{kcal} / \mathrm{mol}$. In contrast, the 'nitration' induced change in HINT scores for Y181 interactions with other I $\kappa \alpha$ residues within $8 \AA$ is consistent with a net stabilizing effect. Major contributions to this positive interaction are the acid/base and hydrogen bond interactions of the nitro-group with R140 of IKB $\alpha$ (Table 1, Fig. 6A).

To experimentally test for this, the R140A I $\kappa \mathrm{B} \alpha$ mutant was constructed, and the relative affinities of wild type and R140A myc-tagged IкB $\alpha$ to NF- $\kappa B$ compared by coimmunoprecipitation with anti-p65 antibody (Fig. 6B). The affinity of the R140A mutant for $\mathrm{NF}-\kappa \mathrm{B}$ is considerably reduced relative to wild type even in the absence of nitration. These results do not allow for any statement on the role of this particular interaction on the effect nitration on I $\mathrm{KB} \alpha / \mathrm{NF}-\kappa \mathrm{B}$ stability. However, they underline the importance of this surface area of $\mathrm{I} \kappa \mathrm{B} \alpha$ in its interactions with $\mathrm{p} 50 / \mathrm{p} 65$ and the potential for their disruption by tyrosine nitration.

\section{Discussion}

The above experimentation indicates a new mechanism for NF- $\mathrm{kB}$ activation. IR is shown to stimulate NF- $\kappa B$ activity by a mechanism in which I $\mathrm{B} \alpha \mathrm{Y} 181$ is nitrated as a consequence of

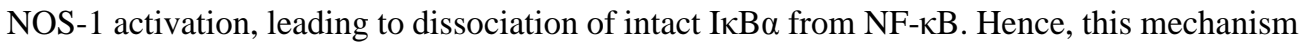
of NF- $\mathrm{KB}$ activation does not depend on IKK dependent phosphorylation and proteolytic degradation of I $\kappa \mathrm{B} \alpha$. Modeling of free energy changes is consistent with the experimental findings that IR-induced Y181 nitration disrupts the noncovalent interactions of Y181 with 


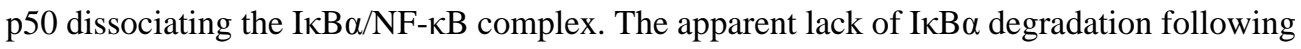
treatment of cells with low IR doses is also in accord with findings that IR at doses $>0.2 \mathrm{~Gy}$ significantly inhibits proteosome activities $(4,6)$. The IR dose response analysis demonstrates a progressive increase in NF- $\mathrm{KB}$ activation up to the highest dose tested, $32 \mathrm{~Gy}$. However, only at IR doses below $8 \mathrm{~Gy}$ is substantial inhibition observed with the NOS inhibitor L-NNA.

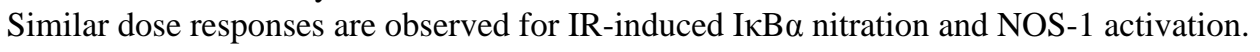

The experimental results suggest that NF- $\mathrm{BB}$ is activated by IR through both, IKK $\beta$ independent and IKK $\beta$-dependent mechanisms. The IKK $\alpha$-independent pathway involving

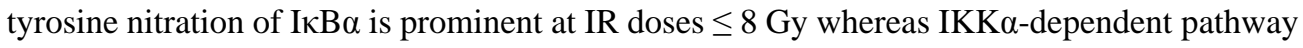
involving I $\kappa \mathrm{B} \alpha$ phosphorylation/proteolysis becomes more prominent at IR doses $>8 \mathrm{~Gy}$. Dose dependent mechanisms are also indicated in the IKK- $\beta$ knockdown experiments. Whereas shRNA treatment completely abrogates TNF $\alpha$-induced NF- $\mathrm{KB}$ activity, it only partially decreases IR-induced activity. The remaining activity is inhibited by NOS inhibitor L-NNA.

Analysis of the kinetics of NF- $\mathrm{KB}$ activation following low or high dose IR is also indicative of different mechanisms. A previous study using electrophoretic mobility shift analysis monitored activation of NF- $\mathrm{kB}$ in HeLa cells after $20 \mathrm{~Gy}$ (52). No activation was observed at $30 \mathrm{~min}$, a slight increase at one hour and maximal activation at two hours. This contrasts with the responses obtained within minutes of exposure to lower doses of IR (Fig 1C,2) or to $\mathrm{TNF} \alpha$ (39). IR-stimulated nitration of I $\mathrm{I} \mathrm{B} \alpha$ is observed at $5 \mathrm{~min}$ post-irradiation at $5 \mathrm{~Gy}$, the

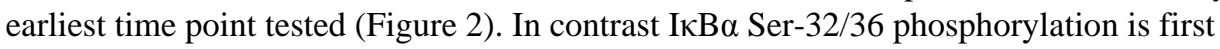
observed at 45 min post-irradiation with $20 \mathrm{~Gy}$ (39).

The IKK $\beta$ dependent and independent pathways are not mutually exclusive. This is suggested by the partial inhibition of NF- $\mathrm{kB}$ signaling at the lower doses of IR by shRNA knockdown of IKK $\beta$. However, the IKK $\beta$-mechanisms may differ depending on IR dose. For example, different mechanisms may reflect the cellular localization of the oxidative/nitrosative events: DNA damage in the nucleus and oxidative/nitrosative events in the cytoplasm. Further experiments are necessary to test this hypothesis. IKK $\beta$ can also modulate NF- $\mathrm{KB}$ transcriptional activity in the cytoplasm through an I $\mathrm{B} \alpha$-independent mechanism: phosphorylation of the p65 subunit in its transactivation domain at S536 (7-10).

NF- $\kappa \mathrm{B}$ activation by reactive nitrogen species has been previously investigated using a $\mathrm{ONOO}^{-}$donor, SIN-1 (11). NF- $\mathrm{KB}$ activity measured with a luciferase-based reporter assay was stimulated by a mechanism not blocked by the proteosome inhibitor, MG132, nor was $\mathrm{I} \kappa \mathrm{B} \alpha$ degradation associated with the stimulation. These experimental findings directly relate to the results reported here with IR. Thus, our results provide a mechanism for how SIN-1 and other cellular $\mathrm{ONOO}^{-}$generating processes can activate NF- $\mathrm{kB}$ signaling.

A previous analysis of several IкB $\alpha$ mutants demonstrated that the Y181A mutation was most

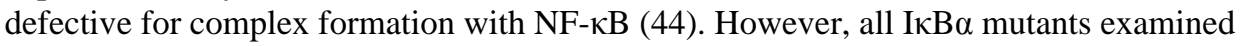
including Y181A still bound NF- $\kappa B$ with nanomolar affinities suggesting that several binding

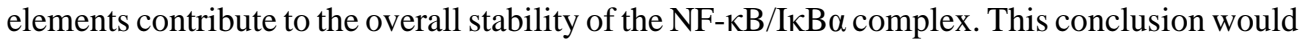
appear to be in conflict with the present findings that mutation of Y181 alone completely blocks

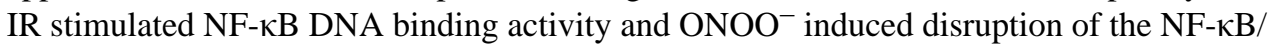
$\mathrm{I} \kappa \mathrm{B} \alpha$ complex. A likely explanation is that nitration of tyrosine is a much more disruptive protein modification than substitution of an alanine for tyrosine. Besides introducing a bulky substituent, tyrosine nitration significantly alters the dipole moment of tyrosine and reduces the phenolic $\mathrm{pK}$ by $2-3$ units effectively introducing a net negative charge in a relatively nonpolar restricted space. Other studies have demonstrated that nitration of a specific tyrosine in proteins can have significant structural and functional consequences for proteins, e.g. (5357). It is also important to note that the studies by Huxford et al (44) used a bacterial expression 
system with a truncated I $\kappa \mathrm{B} \alpha$ lacking both $\mathrm{N}$-and $\mathrm{C}$-terminal elements, including Y305. Nitration of Y305 may have an important role in modulating the stability of the NF- $\kappa B / I \kappa B \alpha$ complex.

Tyrosine-305 of IкB $\alpha$ is also nitrated following radiation or an acute $\mathrm{ONOO}^{-}$treatment. We were unable to model the effects of $\mathrm{Y} 305$ nitration on the I $\kappa \mathrm{B} \alpha / \mathrm{NF}-\kappa \mathrm{B}$ complex stability because both available crystal structures of $\mathrm{I} \kappa \mathrm{B} \alpha / \mathrm{NF}-\kappa \mathrm{B}$ lack the $\mathrm{C}$-terminal regions containing Y305. From the $1 \mathrm{IKN}$ structure, it is clear that a turn in secondary structure occurs around $\mathrm{P} 215$ and the $\mathrm{C}$-terminal portion of $\mathrm{I} \mathrm{KB} \alpha$ wraps on itself and runs along the interface with p65 and p50 subunits of NF- $\mathrm{kB}$. Tyrosine-305 is part of this C-terminal sequence and its nitration can presumably contribute to disruption of non-covalent interactions stabilizing the I $\mathrm{B} \alpha / \mathrm{NF}$ $\kappa \mathrm{B}$ complex. Is Y181 and Y305 nitration cooperative and is nitration of both residues required for rapid dissociation of the complex? From results of our work, it appears that nitration of Y181 is alone sufficient to destabilize the signaling complex, but the kinetics of dissociation of I $\mathrm{I} B \alpha$ from NF- $\kappa \mathrm{B}$ may be affected by additional nitration of Y305. A previous report also provides evidence that phosphorylation of $\mathrm{Y} 305$ increased the in vivo stability of IкB $\alpha$ (58). It is possible that its nitration serves a similar purpose. Some investigations have suggested that nitro-tyrosine may mimic phospho-tyrosine binding sites, e.g. (59). Further experimentation will be necessary to test these mechanisms involving Y305.

Experiments described here and in other published work demonstrate a high degree of selectivity in what tyrosines are nitrated by an acute ONOO- treatment (60). If complexed with $\mathrm{p} 50 / \mathrm{p} 65$, I $\mathrm{B} \alpha$ is nitrated on only 2 of 8 tyrosines following an IR exposure of intact cells or treatment of cell lysates with $\mathrm{ONOO}^{-}$. With the same in vitro conditions attempts to nitrate purified I $\kappa \mathrm{B} \alpha$ with $\mathrm{ONOO}^{-}$have proven unsuccessful (C.S. Rabender, unpublished data). This suggests that the tertiary or quaternary structures of $\mathrm{I} \kappa \mathrm{B} \alpha$ are important in determing susceptibiblity to nitration by $\mathrm{ONOO}^{-}$. An analysis of nitrated proteins suggests that no specific structural feature alone determines nitration $(60,61)$. Tyrosines located in loop structures have increased probability for nitration $(60,61)$ and Y181 is located in the $\beta$-turn loop between the $3^{\text {rd }}$ and $4^{\text {th }}$ ankyrin repeats.

No amino acid consensus sequence has been identified although it has been speculated that nitrated tyrosines are generally but not always near acidic amino acid residues (60). This is true for Y305 with one glutamate in close proximity (KPFLY ${ }^{305} \mathrm{EIK}$ ), but this is not the case for Y181 (KATNY ${ }^{181}$ NGHT). There are also no acidic amino acids from p50 or p65 at the interface near $\mathrm{Y} 181$ of IкB $\alpha$ that can contribute to this possible electrostatic environment. A more recent report on endogenously nitrated proteins of the brain argues for the importance of a positively charged amino acid near sites of nitration (61). This criterion is fulfilled by both Y181 and Y305 of IאB $\alpha$.

The short half-life of $\mathrm{ONOO}^{-}$predicts that proximity of the protein to $\mathrm{ONOO}^{-}$source is also important in selectivity $(19,60)$. The primary source of IR-stimulated cellular $\mathrm{ONOO}^{-}$is the mitochondrion either by activity of a mitochondrial NOS-1 isoform or as a consequence of respiration generated superoxide anion that reacts with relatively stable $\mathrm{NO}^{*}$ produced elsewhere in the cell $(16,19,60,62)$. A reversible mitochondrial protein tyrosine nitration initiated by hypoxia/reoxygenation has been described (62) and there are reports of mitochondrial localization of I $\kappa \mathrm{B} \alpha / \mathrm{NF}-\kappa \mathrm{B}(63,64)$.

Transient and localized generation of ONOO- may also explain why the results presented here differ from those obtained in some but not all studies on the effects of reactive nitrogen species on NF- $\mathrm{kB}$ activity $(13-15,65)$. High concentrations of $\mathrm{NO}^{\bullet} / \mathrm{ONOO}^{-}$donors and/or prolonged exposure times inhibit NF- $\mathrm{KB}$ activity, e.g. 6-24 hr (15). This contrasts with the transient generation of $\mathrm{ONOO}^{-}$achieved by a short IR exposure of cells or a single bolus addition of 
$\mathrm{ONOO}^{-}$(half life $<1 \mathrm{sec}$ ) to cell lysates. The transient nature of these treatments would be predictive of a higher degree of specificity in the nitration process. This is not only seen in terms of what tyrosines are nitrated but also in terms of whether other $\mathrm{ONOO}^{-}$induced oxidative events have occurred. Under the conditions used in the present experiments there is no evidence for nitration of either p65 or p50. There is also no evidence for the oxidation of either a cysteine or methionine. On the other hand a single Y181F mutation was sufficient to block IR stimulated NF- $\mathrm{kB}$ DNA binding activity and $\mathrm{ONOO}^{-}$induced dissociation of the NF$\kappa \mathrm{B} / \mathrm{I} \kappa \mathrm{B} \alpha$ complex. Combined with the effects of NOS inhibition and structural analysis, this is compelling evidence for a key role for Y181 nitration in IR stimulation of NF- $\mathrm{\kappa B}$ activation.

An important characteristic of signal transduction pathways is their reversibility. The transient and relatively mild oxidative treatments used here may also have facilitated the apparent reversibility of the IR-stimulated I $\mathrm{B} \alpha$ tyrosine nitration. Although the mechanism of reversibility is not known, proteolytic degradation followed by resynthesis does not appear to be involved. This also is the case with the reversible nitration of mitochondrial proteins after hypoxia-reoxygenation (62). There are reports of denitrase activities in eukaryotic cells but underlying denitration mechanisms of eukaryotic cells remain undefined (66-68).

Because tyrosine-nitration is not commonly studied in the context of signal transduction, it may be an undiscovered but important component for NF-kB activation by stimuli other than IR. A previous report that mitochondria-generated superoxide anion and $\mathrm{ONOO}^{-}$are important for TNF $\alpha$-stimulated NF- $\kappa B$ activation is interesting in this regard (69). Nitration and disruption of the interactions between Y181 of I $\mathrm{KB} \alpha$ with $\mathrm{p} 50$ may be representative of a posttranslational modification and structural motif critical for the stability of other protein complexes.

\section{Supplementary Material}

Refer to Web version on PubMed Central for supplementary material.

\section{Abbreviations}

NOS-1, constitutive NO ${ }^{\bullet}$ synthase; TNF, tumor necrosis factor; IKK, IאB kinase; IR, ionizing radiation; L-NNA, $\mathrm{N}^{\mathrm{G}}$-Nitro-L-arginine.

\section{References}

1. Ghosh S, Karin M. Missing pieces in the NF-kappaB puzzle. Cell 2002;109:S81-S96. [PubMed: 11983155]

2. Beg AA, Baldwin AS Jr. The I kappa B proteins: multifunctional regulators of Rel/NF-kappa B transcription factors. Genes Dev 1993;7:2064-2070. [PubMed: 8224838]

3. Criswell T, Leskov K, Miyamoto S, Luo G, Boothman DA. Transcription factors activated in mammalian cells after clinically relevant doses of ionizing radiation. Oncogene 2003;22:5813-5827. [PubMed: 12947388]

4. Pajonk F, McBride WH. The proteasome in cancer biology and treatment. Radiat Res 2001;156:447459. [PubMed: 11604057]

5. Raju U, Gumin GJ, Noel F, Tofilon PJ. IkappaBalpha degradation is not a requirement for the X-rayinduced activation of nuclear factor kappaB in normal rat astrocytes and human brain tumour cells. Int J Radiat Biol 1998;74:617-624. [PubMed: 9848280]

6. Liu X, Huang W, Li C, Li P, Yuan J, Li X, Qiu XB, Ma Q, Cao C. Interaction between c-Abl and Arg tyrosine kinases and proteasome subunit PSMA7 regulates proteasome degradation. Mol Cell 2006;22:317-327. [PubMed: 16678104] 
7. Hall G, Singh IS, Hester L, Hasday JD, Rogers TB. Inhibitor-kappaB kinase-beta regulates LPSinduced TNF-alpha production in cardiac myocytes through modulation of NF-kappaB p65 subunit phosphorylation. Am J Physiol Heart Circ Physiol 2005;289:H2103-H2111. [PubMed: 15980040]

8. Sakurai H, Chiba H, Miyoshi H, Sugita T, Toriumi W. IkappaB kinases phosphorylate NF-kappaB p65 subunit on serine 536 in the transactivation domain. J Biol Chem 1999;274:30353-30356. [PubMed: 10521409]

9. Sasaki CY, Barberi TJ, Ghosh P, Longo DL. Phosphorylation of RelA/p65 on serine 536 defines an I \{kappa\}B\{alpha\}-independent NF-\{kappa\}B pathway. J Biol Chem 2005;280:34538-34547. [PubMed: 16105840]

10. Yang F, Tang E, Guan K, Wang CY. IKK beta plays an essential role in the phosphorylation of RelA/ p65 on serine 536 induced by lipopolysaccharide. J Immunol 2003;170:5630-5635. [PubMed: 12759443]

11. Janssen-Heininger YM, Macara I, Mossman BT. Cooperativity between oxidants and tumor necrosis factor in the activation of nuclear factor (NF)-kappaB: requirement of Ras/mitogen-activated protein kinases in the activation of NF-kappaB by oxidants. Am J Respir Cell Mol Biol 1999;20:942-952. [PubMed: 10226064]

12. Levrand S, Pesse B, Feihl F, Waeber B, Pacher P, Rolli J, Schaller MD, Liaudet L. Peroxynitrite Is a Potent Inhibitor of NF-\{kappa $\}$ B Activation Triggered by Inflammatory Stimuli in Cardiac and Endothelial Cell Lines. J Biol Chem 2005;280:34878-34887. [PubMed: 16079150]

13. Marshall HE, Stamler JS. Inhibition of NF-kappa B by S-nitrosylation. Biochemistry 2001;40:16881693. [PubMed: 11327828]

14. Matata BM, Galinanes M. Peroxynitrite is an essential component of cytokines production mechanism in human monocytes through modulation of nuclear factor-kappa B DNA binding activity. J Biol Chem 2002;277:2330-2335. [PubMed: 11706022]

15. Park SW, Huq MD, Hu X, Wei LN. Tyrosine nitration on p65: a novel mechanism to rapidly inactivate nuclear factor-kappaB. Mol Cell Proteomics 2005;4:300-309. [PubMed: 15657065]

16. Kanai A, Epperly M, Pearce L, Birder L, Zeidel M, Meyers S, Greenberger J, de Groat W, Apodaca G, Peterson J. Differing roles of mitochondrial nitric oxide synthase in cardiomyocytes and urothelial cells. Am J Physiol Heart Circ Physiol 2004;286:H13-H21. [PubMed: 14684357]

17. Leach JK, Black SM, Schmidt-Ullrich RK, Mikkelsen RB. Activation of constitutive nitric-oxide synthase activity is an early signaling event induced by ionizing radiation. J Biol Chem 2002;277:15400-15406. [PubMed: 11856735]

18. Leach JK, Van Tuyle G, Lin PS, Schmidt-Ullrich R, Mikkelsen RB. Ionizing radiation-induced, mitochondria-dependent generation of reactive oxygen/nitrogen. Cancer research 2001;61:3894 3901. [PubMed: 11358802]

19. Mikkelsen RB, Wardman P. Biological chemistry of reactive oxygen and nitrogen and radiationinduced signal transduction mechanisms. Oncogene 2003;22:5734-5754. [PubMed: 12947383]

20. Barrett DM, Black SM, Todor H, Schmidt-Ullrich RK, Dawson KS, Mikkelsen RB. Inhibition of protein-tyrosine phosphatases by mild oxidative stresses is dependent on S-nitrosylation. J Biol Chem 2005;280:14453-14461. [PubMed: 15684422]

21. Phung YT, Black SM. Use of chimeric forms of neuronal nitric-oxide synthase as dominant negative mutants. IUBMB Life 1999;48:333-338. [PubMed: 10690648]

22. Amorino GP, Hamilton VM, Valerie K, Dent P, Lammering G, Schmidt-Ullrich RK. Epidermal growth factor receptor dependence of radiation-induced transcription factor activation in human breast carcinoma cells. Mol Biol Cell 2002;13:2233-2244. [PubMed: 12134064]

23. Shevchenko A, Wilm M, Vorm O, Mann M. Mass spectrometric sequencing of proteins silver-stained polyacrylamide gels. Anal Chem 1996;68:850-858. [PubMed: 8779443]

24. Schmidt MW, Baldridge KK, Boatz JA, Elbert ST, Gordon MS, Jensen JH, Koseki S, Matsunaga N, Nguyen KA, Su SJ, Windus TL, Dupuis M, Montgomery JA. General atomic and molecular electronic structure system. Journal of Computational Chemistry 1993;14:1347-1363.

25. MacKerell AD, Bashford D, Bellott M, Dunbrack RL, Evanseck JD, Field MJ, Fischer S, Gao J, Guo H, Ha S, Joseph-McCarthy D, Kuchnir L, Kuczera K, Lau FTK, Mattos C, Michnick S, Ngo T, Nguyen DT, Prodhom B, Reiher WE, Roux B, Schlenkrich M, Smith JC, Stote R, Straub J, Watanabe 
M, Wiorkiewicz-Kuczera J, Yin D, Karplus M. All-Atom Empirical Potential for Molecular Modeling and Dynamics Studies of Proteins. J. Phys. Chem. B 1998;102:3586-3616.

26. Humphrey W, Dalke A, Schulten K. VMD: visual molecular dynamics. J Mol Graph 1996;14:3338. 27-38. [PubMed: 8744570]

27. Kale L, Skeel R, Bhandarkar M, Brunner R, Gursoy A, Krawetz N, Phillips J, Shinozaki A, Varadarajan K, Schulten K. NAMD2: Greater Scalability for Parallel Molecular Dynamics. Journal of Computational Physics 1999;151:283-312.

28. Jacobs MD, Harrison SC. Structure of an IkappaBalpha/NF-kappaB complex. Cell 1998;95:749-758. [PubMed: 9865693]

29. Huxford T, Huang DB, Malek S, Ghosh G. The crystal structure of the IkappaBalpha/NF-kappaB complex reveals mechanisms of NF-kappaB inactivation. Cell 1998;95:759-770. [PubMed: 9865694]

30. Amadasi A, Spyrakis F, Cozzini P, Abraham DJ, Kellogg GE, Mozzarelli A. Mapping the energetics of water-protein and water-ligand interactions with the "natural" HINT forcefield: predictive tools for characterizing the roles of water in biomolecules. J Mol Biol 2006;358:289-309. [PubMed: 16497327]

31. Kellogg GE, Fornabaio M, Chen DL, Abraham DJ, Spyrakis F, Cozzini P, Mozzarelli A. Tools for building a comprehensive modeling system for virtual screening under real biological conditions: The Computational Titration algorithm. J Mol Graph Model 2006;24:434-439. [PubMed: 16236534]

32. Cozzini P, Fornabaio M, Marabotti A, Abraham DJ, Kellogg GE, Mozzarelli A. Free energy of ligand binding to protein: evaluation of the contribution of water molecules by computational methods. Curr Med Chem 2004;11:3093-3118. [PubMed: 15579003]

33. Cozzini P, Fornabaio M, Marabotti A, Abraham DJ, Kellogg GE, Mozzarelli A. Simple, intuitive calculations of free energy of binding for protein-ligand complexes. 1. Models without explicit constrained water. J Med Chem 2002;45:2469-2483. [PubMed: 12036355]

34. Kellogg GE, Burnett JC, Abraham DJ. Very empirical treatment of solvation and entropy: a force field derived from log Po/w. J Comput Aided Mol Des 2001;15:381-393. [PubMed: 11349819]

35. Marabotti A, Balestreri L, Cozzini P, Mozzarelli A, Kellogg GE, Abraham DJ. HINT predictive analysis of binding between retinol binding protein and hydrophobic ligands. Bioorg Med Chem Lett 2000;10:2129-2132. [PubMed: 10999486]

36. Rodel F, Hantschel M, Hildebrandt G, Schultze-Mosgau S, Rodel C, Herrmann M, Sauer R, Voll RE. Dose-dependent biphasic induction and transcriptional activity of nuclear factor kappa B (NFkappaB) in EA.hy.926 endothelial cells after low-dose X-irradiation. Int J Radiat Biol 2004;80:115123. [PubMed: 15164793]

37. Ueda T, Akiyama N, Sai H, Oya N, Noda M, Hiraoka M, Kizaka-Kondoh S. c-IAP2 is induced by ionizing radiation through NF-kappaB binding sites. FEBS letters 2001;491:40-44. [PubMed: 11226415]

38. Wang T, Hu YC, Dong S, Fan M, Tamae D, Ozeki M, Gao Q, Gius D, Li JJ. Co-activation of ERK, NF-kappaB, and GADD45beta in response to ionizing radiation. J Biol Chem 2005;280:1259312601. [PubMed: 15642734]

39. Hoffmann A, Levchenko A, Scott ML, Baltimore D. The IkappaB-NF-kappaB signaling module: temporal control and selective gene activation. Science 2002;298:1241-1245. [PubMed: 12424381]

40. Nelson DE, Ihekwaba AE, Elliott M, Johnson JR, Gibney CA, Foreman BE, Nelson G, See V, Horton CA, Spiller DG, Edwards SW, McDowell HP, Unitt JF, Sullivan E, Grimley R, Benson N, Broomhead D, Kell DB, White MR. Oscillations in NF-kappaB signaling control the dynamics of gene expression. Science 2004;306:704-708. [PubMed: 15499023]

41. Imbert V, Rupec RA, Livolsi A, Pahl HL, Traenckner EB, Mueller-Dieckmann C, Farahifar D, Rossi B, Auberger P, Baeuerle PA, Peyron JF. Tyrosine phosphorylation of I kappa B-alpha activates NFkappa B without proteolytic degradation of I kappa B-alpha. Cell 1996;86:787-798. [PubMed: 8797825]

42. Bagnasco P, MacMillan-Crow LA, Greendorfer JS, Young CJ, Andrews L, Thompson JA. Peroxynitrite modulates acidic fibroblast growth factor (FGF-1) activity. Arch Biochem Biophys 2003;419:178-189. [PubMed: 14592461] 
43. Batthyany C, Souza JM, Duran R, Cassina A, Cervenansky C, Radi R. Time course and site(s) of cytochrome c tyrosine nitration by peroxynitrite. Biochemistry 2005;44:8038-8046. [PubMed: 15924423]

44. Huxford T, Mishler D, Phelps CB, Huang DB, Sengchanthalangsy LL, Reeves R, Hughes CA, Komives EA, Ghosh G. Solvent exposed noncontacting amino acids play a critical role in NF-kappaB/ IkappaBalpha complex formation. J Mol Biol 2002;324:587-597. [PubMed: 12460563]

45. Takada Y, Mukhopadhyay A, Kundu GC, Mahabeleshwar GH, Singh S, Aggarwal BB. Hydrogen peroxide activates NF-kappa B through tyrosine phosphorylation of I kappa B alpha and serine phosphorylation of p65: evidence for the involvement of I kappa B alpha kinase and Syk proteintyrosine kinase. J Biol Chem 2003;278:24233-24241. [PubMed: 12711606]

46. Burow ME, Weldon CB, Tang Y, Navar GL, Krajewski S, Reed JC, Hammond TG, Clejan S, Beckman BS. Differences in susceptibility to tumor necrosis factor alpha-induced apoptosis among MCF-7 breast cancer cell variants. Cancer research 1998;58:4940-4946. [PubMed: 9810003]

47. Abraham DJ, Kellogg GE, Holt JM, Ackers GK. Hydropathic analysis of the non-covalent interactions between molecular subunits of structurally characterized hemoglobins. J Mol Biol 1997;272:613632. [PubMed: 9325116]

48. Burnett JC, Kellogg GE, Abraham DJ. Computational methodology for estimating changes in free energies of biomolecular association upon mutation. The importance of bound water in dimertetramer assembly for beta 37 mutant hemoglobins. Biochemistry 2000;39:1622-1633. [PubMed: 10677211]

49. Burnett JC, Botti P, Abraham DJ, Kellogg GE. Computationally accessible method for estimating free energy changes resulting from site-specific mutations of biomolecules: systematic model building and structural/hydropathic analysis of deoxy and oxy hemoglobins. Proteins 2001;42:355377. [PubMed: 11151007]

50. Tawfik DS, Chap R, Eshhar Z, Green BS. pH on-off switching of antibody-hapten binding by sitespecific chemical modification of tyrosine. Protein Eng 1994;7:431-434. [PubMed: 8177892]

51. Oneda $\mathrm{H}$, Inouye $\mathrm{K}$. Effect of nitration on the activity of bovine erythrocyte $\mathrm{Cu}, \mathrm{Zn}$-superoxide dismutase (BESOD) and a kinetic analysis of its dimerizationdissociation reaction as examined by subunit exchange between the native and nitrated BESODs. J Biochem (Tokyo) 2003;134:683-690. [PubMed: 14688234]

52. Li N, Karin M. Ionizing radiation and short wavelength UV activate NF-kappaB through two distinct mechanisms. Proceedings of the National Academy of Sciences of the United States of America 1998;95:13012-13017. [PubMed: 9789032]

53. Hodara R, Norris EH, Giasson BI, Mishizen-Eberz AJ, Lynch DR, Lee VM, Ischiropoulos H. Functional consequences of alpha-synuclein tyrosine nitration: diminished binding to lipid vesicles and increased fibril formation. J Biol Chem 2004;279:47746-47753. [PubMed: 15364911]

54. Ischiropoulos H, Gow A. Pathophysiological functions of nitric oxide-mediated protein modifications. Toxicology 2005;208:299-303. [PubMed: 15691593]

55. Ji Y, Neverova I, Van Eyk JE, Bennett BM. Nitration of tyrosine 92 mediates the activation of rat microsomal glutathione s-transferase by peroxynitrite. J Biol Chem 2006;281:1986-1991. [PubMed: 16314419]

56. Knyushko TV, Sharov VS, Williams TD, Schoneich C, Bigelow DJ. 3-Nitrotyrosine modification of SERCA2a in the aging heart: a distinct signature of the cellular redox environment. Biochemistry 2005;44:13071-13081. [PubMed: 16185075]

57. Radi R. Nitric oxide, oxidants, and protein tyrosine nitration. Proceedings of the National Academy of Sciences of the United States of America 2004;101:4003-4008. [PubMed: 15020765]

58. Kawai H, Nie L, Yuan ZM. Inactivation of NF-kappaB-dependent cell survival, a novel mechanism for the proapoptotic function of c-Abl. Mol Cell Biol 2002;22:6079-6088. [PubMed: 12167702]

59. Mallozzi C, Di Stasi AM, Minetti M. Nitrotyrosine mimics phosphotyrosine binding to the SH2 domain of the src family tyrosine kinase lyn. FEBS letters 2001;503:189-195. [PubMed: 11513880]

60. Ischiropoulos H. Biological selectivity and functional aspects of protein tyrosine nitration. Biochem Biophys Res Commun 2003;305:776-783. [PubMed: 12763060] 
61. Sacksteder CA, Qian WJ, Knyushko TV, Wang H, Chin MH, Lacan G, Melega WP, Camp DG 2nd, Smith RD, Smith DJ, Squier TC, Bigelow DJ. Endogenously Nitrated Proteins in Mouse Brain: Links to Neurodegenerative Disease. Biochemistry 2006;45:8009-8022. [PubMed: 16800626]

62. Aulak KS, Koeck T, Crabb JW, Stuehr DJ. Dynamics of protein nitration in cells and mitochondria. Am J Physiol Heart Circ Physiol 2004;286:H30-H38. [PubMed: 14684358]

63. Bottero V, Rossi F, Samson M, Mari M, Hofman P, Peyron JF. Ikappa b-alpha, the NF-kappa B inhibitory subunit, interacts with ANT, the mitochondrial ATP/ADP translocator. J Biol Chem 2001;276:21317-21324. [PubMed: 11287411]

64. Cogswell PC, Kashatus DF, Keifer JA, Guttridge DC, Reuther JY, Bristow C, Roy S, Nicholson DW, Baldwin AS Jr. NF-kappa B and I kappa B alpha are found in the mitochondria. Evidence for regulation of mitochondrial gene expression by NF-kappa B. J Biol Chem 2003;278:2963-2968. [PubMed: 12433922]

65. Reynaert NL, Ckless K, Korn SH, Vos N, Guala AS, Wouters EF, van der Vliet A, Janssen-Heininger YM. Nitric oxide represses inhibitory kappaB kinase through S-nitrosylation. Proceedings of the National Academy of Sciences of the United States of America 2004;101:8945-8950. [PubMed: 15184672]

66. Gorg B, Qvartskhava N, Voss P, Grune T, Haussinger D, Schliess F. Reversible inhibition of mammalian glutamine synthetase by tyrosine nitration. FEBS letters 2007;581:84-90. [PubMed: 17174954]

67. Irie Y, Saeki M, Kamisaki Y, Martin E, Murad F. Histone H1.2 is a substrate for denitrase, an activity that reduces nitrotyrosine immunoreactivity in proteins. Proceedings of the National Academy of Sciences of the United States of America 2003;100:5634-5639. [PubMed: 12719531]

68. Kuo WN, Kanadia RN, Shanbhag VP, Toro R. Denitration of peroxynitrite-treated proteins by 'protein nitratases' from rat brain and heart. Mol Cell Biochem 1999;201:11-16. [PubMed: 10630617]

69. Higuchi M, Manna SK, Sasaki R, Aggarwal BB. Regulation of the activation of nuclear factor kappaB by mitochondrial respiratory function: evidence for the reactive oxygen species-dependent and independent pathways. Antioxid Redox Signal 2002;4:945-955. [PubMed: 12573143] 

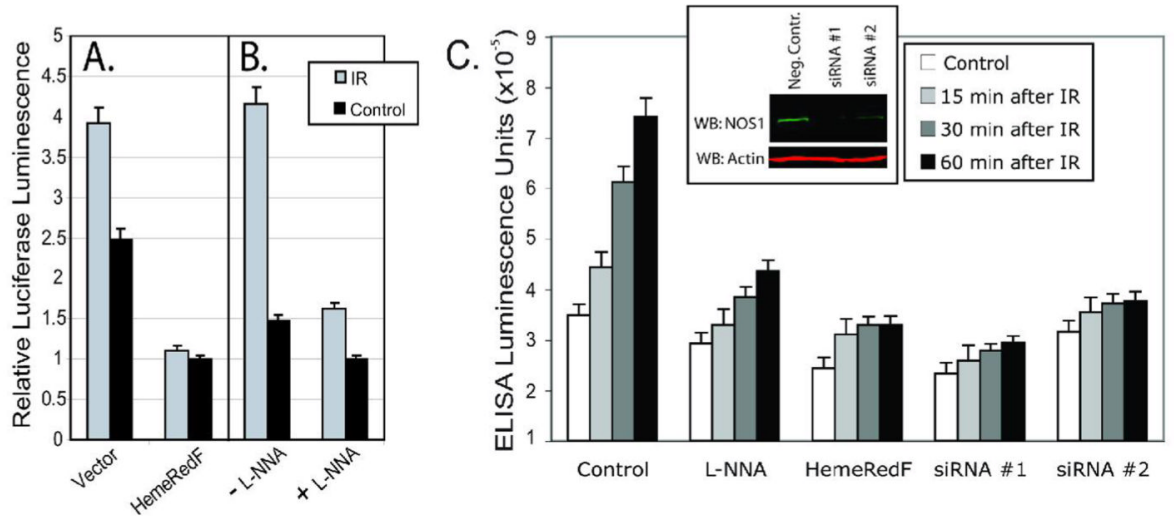

D.

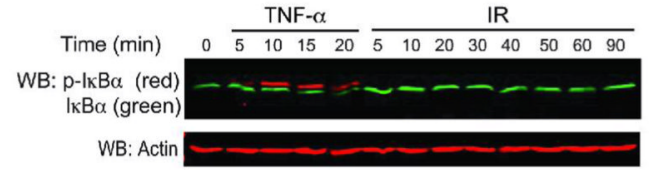

E.

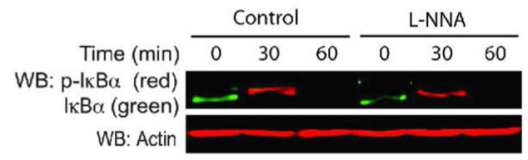

F.

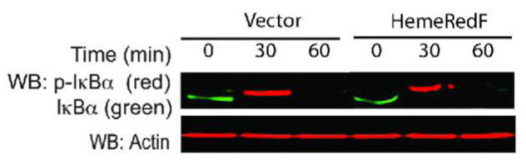

G.

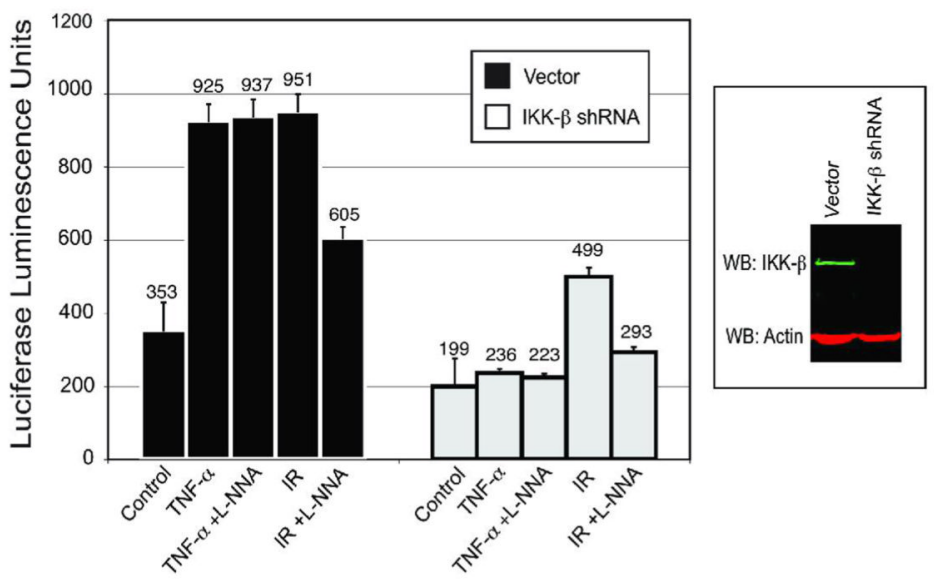

$176 \times 240 \mathrm{~mm}(300 \times 300 \mathrm{DPI})$

Figure 1.

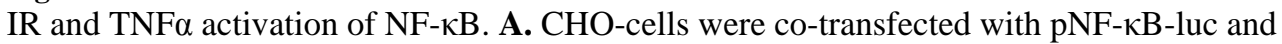
either pHemeRedF (dominant negative mutant of NOS-1) or an empty vector as a control. Cells were radiated $(5 \mathrm{~Gy}) 48 \mathrm{~h}$ after transfection and luciferase activity was measured in cell lysates $24 \mathrm{~h}$ later. B. $44 \mathrm{hrs}$ after transfection with pNF-kB-luc, cells were treated with $100 \mathrm{nM} \mathrm{L-}$ NNA for $4 \mathrm{~h}$ prior to a $5 \mathrm{~Gy}$ IR exposure. Experimental data (for A and B) are presented as means \pm SD for quadruplicate samples and are representative of experiments performed in triplicate. C. CHO-cells were seeded and transfected with NOS1 siRNAs on the same day or with HemeRedF plasmid 24 hours later. Incubation with 100nM L-NNA was performed $4 \mathrm{~h}$ before radiation. Cells were radiated ( $5 \mathrm{~Gy}$ ) $48 \mathrm{~h}$ after seeding and harvested at the given time- 
points after IR. Nuclear extracts of the cells were prepared and normalized relative to the total protein concentration. The ELISA assay was performed to measure specific DNA binding activity of NF- $\mathrm{KB}$ in the nuclear extracts. Experimental data are presented as means $\pm \mathrm{SD}$ for triplicate samples. Embedded panel shows level of NOS1 48-h after isRNAs transfection. D. MCF-7 cells were irradiated at $5 \mathrm{~Gy}$ and cell lysates analyzed by immunoblotting for phospho-

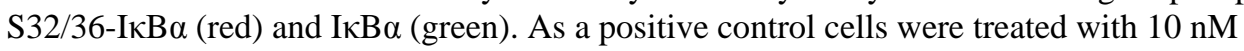
$\mathrm{TNF} \alpha$. Equal loading was verified by blotting with anti-actin (bottom panel). E. Cells were pretreated with $100 \mathrm{nM} \mathrm{L-NNA}$ for $4 \mathrm{~h}$ prior to adding $10 \mathrm{nM}$ of TNF $\alpha$. Equal loading was verified by western blotting of cell lysates with anti-actin (bottom panel). F. MCF-7 cells were transfected with pHemeRedF or empty vector as a control. Cells were treated with TNF $\alpha$ (10nM) $48 \mathrm{~h}$ after transfection. Equal loading was verified by immunoblotting cell lysates with

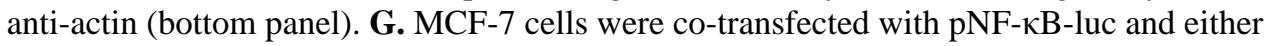
pIKK- $\beta$ shRNA or the empty vector as a control. Cells were radiated ( $5 \mathrm{~Gy}$ ) or treated with $\mathrm{TNF} \alpha 48 \mathrm{~h}$ after transfection and luciferase activity was measured in cell lysates $24 \mathrm{~h}$ later. LNNA (100nM) was added to the cell cultures 4 hrs prior to IR exposure or TNF $\alpha$ treatment. Experimental data are presented as means $\pm \mathrm{SD}$ for triplicate samples. Right panel: Western blots of cell lysates validating the effectiveness of IKK $\beta$ shRNA treatment $-48 \mathrm{~h}$ after transfection. Cell lysates were probed with anti-IKK $\beta$ (green) and anti-actin antibody (red) as a loading control. 
A.

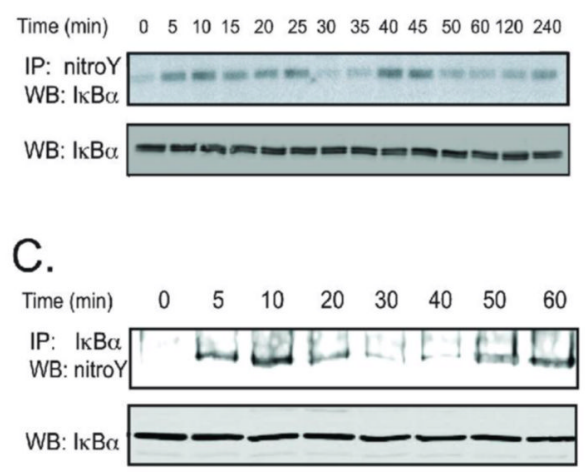

E.

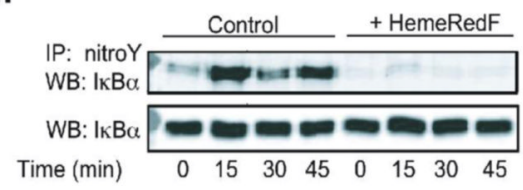

F.
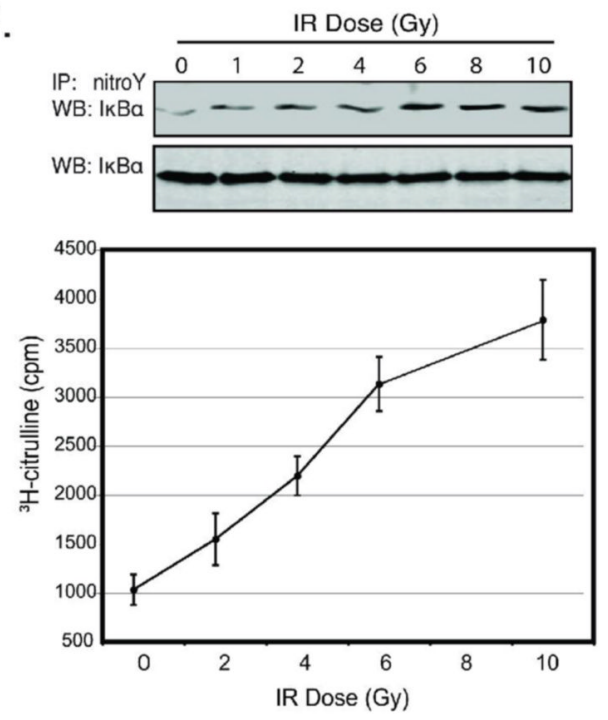

B.

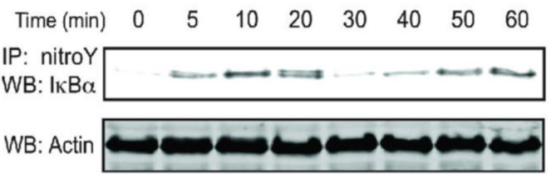

D.

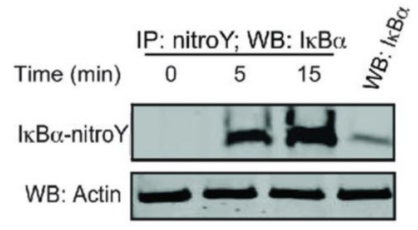

G.

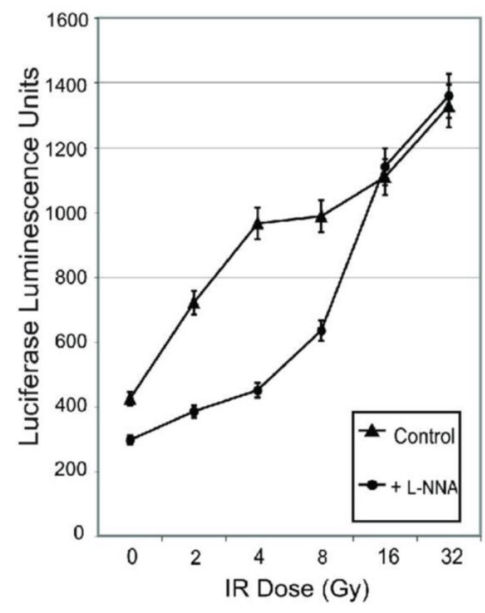

$177 \times 230 \mathrm{~mm}(300 \times 300 \mathrm{DPI})$

Figure 2.

IR dose dependence of NOS-1 activity, NF- $\kappa B$ induction and I $\kappa \mathrm{B} \alpha$ tyrosine-nitration. A. Tyrosine nitration of I $\kappa \mathrm{B} \alpha$ after IR ( $5 \mathrm{~Gy}$ ) was monitored in CHO-cells transfected with pCMVI $\mathrm{B} \alpha$-wild type and irradiated $48 \mathrm{~h}$ after transfection. Anti-nitro-tyrosine immunoprecipitates analyzed for I $\kappa \mathrm{B} \alpha$ by Western blotting. Equal loading was verified by immunoblotting cell lysates with anti-IкB $\alpha$ antibody (bottom panel). B. Radiation-stimulated tyrosine nitration of endogenous I $\kappa \mathrm{B} \alpha$ in MCF-7 cells. MCF-7 cells were radiated (5 Gy) and cell lysate prepared at the indicated time points. Anti-nitro-tyrosine immunoprecipitates were analyzed with anti$\mathrm{I} \kappa \mathrm{B} \alpha$ antibody. For loading controls, equal amounts of each cell lysate were fractionated by electrophoresis and immunoblotted with anti-actin antibody. C. MCF-7 cells were radiated as 
in Fig. 2B. Anti-IкB $\alpha$ immunoprecipitates were probed with anti-nitro-tyrosine antibody. For loading controls, equal amounts of each immunoprecipitate were fractionated by

electrophoresis and blotted with anti-IкB $\alpha$. D. Whole-cell extracts from non-transfected cells were prepared at 0 (no IR), and 5 and 15 min post-IR ( 5 Gy). Anti-nitro-tyrosine immunoprecipitates from total cell extracts were analyzed by immunoblotting with anti-

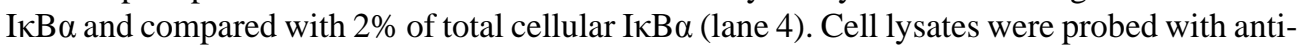
actin antibody as loading control (bottom panel). E. NOS activity modulates I $\kappa \mathrm{B} \alpha$ tyrosinenitration after IR (5 Gy). CHO cells were co-transfected with $\mathrm{pI} \kappa \mathrm{B} \alpha$ and pHemeRedF or an empty vector. Alternatively, cells transfected with $\mathrm{pI \kappa B} \alpha$ were treated with $100 \mathrm{nM}$ L-NNA 4 $\mathrm{h}$ prior to irradiation. The experimental protocol in Fig. $2 \mathrm{C}$ was used to determine the effects of inhibiting NOS activity by HemeRedF expression or incubating cells with L-NNA (upper panel). Bottom panels are loading controls of cell lysates probed with anti-IкB $\alpha$ antibody. F. MCF-7 cells were lysed 15 minutes after exposure to different IR doses. Anti-nitro-tyrosine immunoprecipitates were analyzed by immunoblotting with anti-IкB $\alpha$. Cell lysates were probed with anti-IкB $\alpha$ to verify equal loading (lower panel); Graph: Arginine-citrulline conversion assay with different doses of IR was performed as previously described $(17,20)$. Results are presented as the average of triplicate samples $\pm \mathrm{SD}$; $\mathbf{G}$. L-NNA inhibition of NF$\kappa \mathrm{B}$ activity after different doses of IR. MCF-7 cells were transfected with pNF- $\kappa \mathrm{B}-\mathrm{luc}$ and irradiated $48 \mathrm{~h}$ after transfection. Luciferase activity was measured in cell lysates $24 \mathrm{~h}$ later. Cells were incubated with $100 \mathrm{nM} \mathrm{L-NNA}$ for $4 \mathrm{~h}$ prior to a IR exposure. 


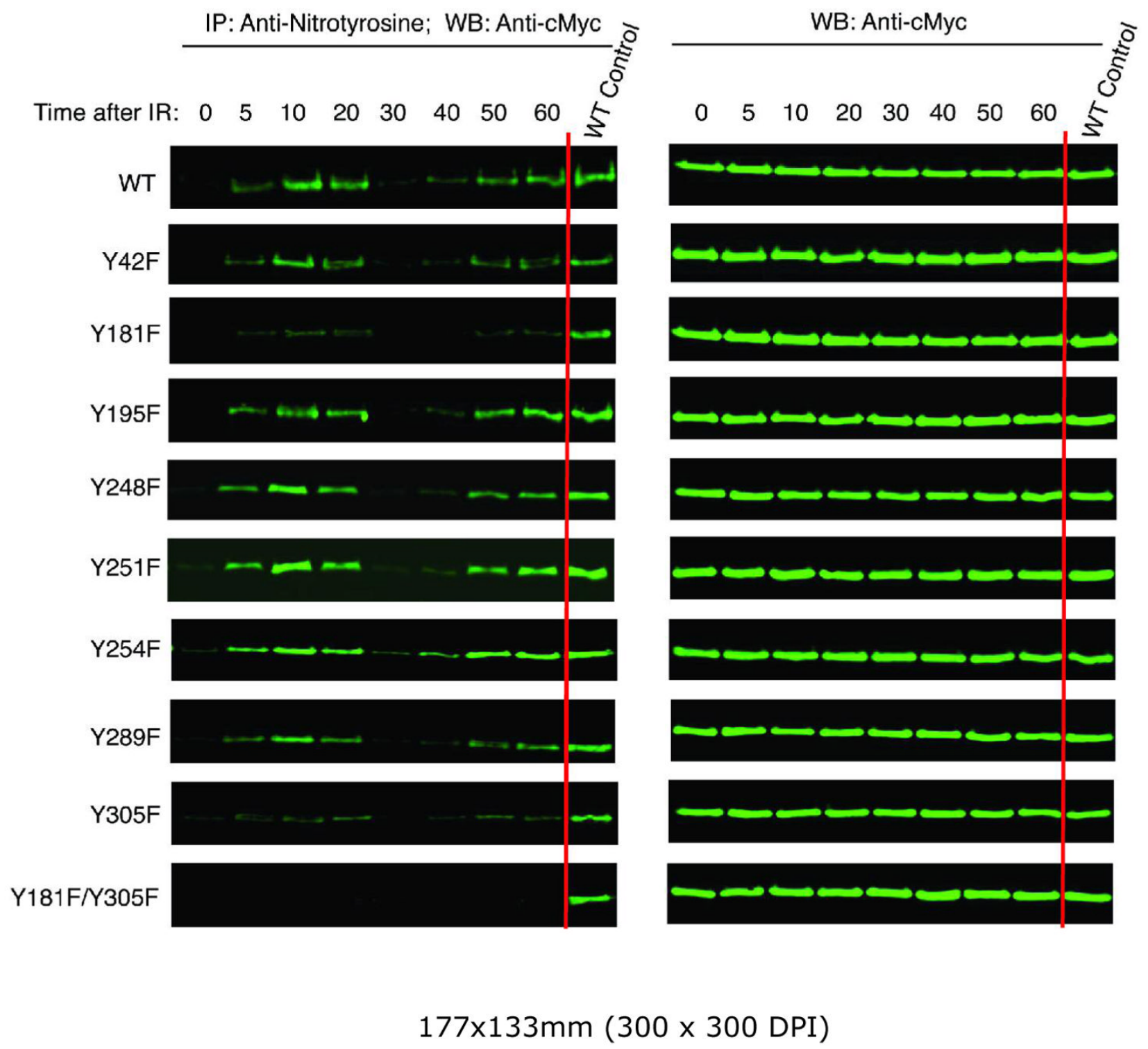

Figure 3.

Site-directed mutagenesis and identification of $\mathrm{I} \kappa \mathrm{B} \alpha$ tyrosines nitrated after radiation. $\mathrm{CHO}$ cells were transfected with cMyc-tagged I $\kappa \mathrm{B} \alpha$ wild type, different $\mathrm{Y} \rightarrow \mathrm{F}$ mutants, and double mutant $181 / 305 \mathrm{YY} \rightarrow \mathrm{FF}$ and irradiated with $5 \mathrm{~Gy} 48 \mathrm{~h}$ after transfection. Cells were lysed at the certain time-points after IR. Anti-nitro-tyrosine immunoprecipitates were analyzed by immunoblotting with anti-cMyc (left panels). Cell lysates were probed with anti-cMyc to verify equal loading of cMyc-tagged I $\kappa \mathrm{B} \alpha$ (right panels). As a positive control and to facilitate comparisons, cMyc-tagged $\mathrm{I} \kappa \mathrm{B} \alpha$ in cell lysates of over-expressing cells was nitrated with $50 \mu \mathrm{M} \mathrm{ONOO}^{-}$. The nitrated $\mathrm{I} \kappa \mathrm{B} \alpha$ as immunopurified as described and run on each blot (the last line of the each panel). 
A.

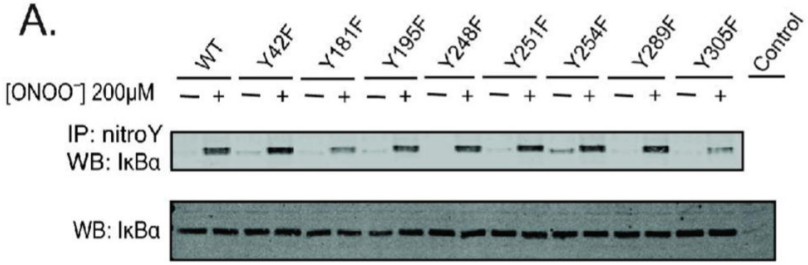

C.

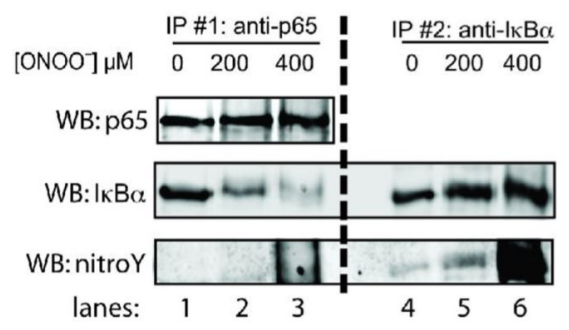

B.

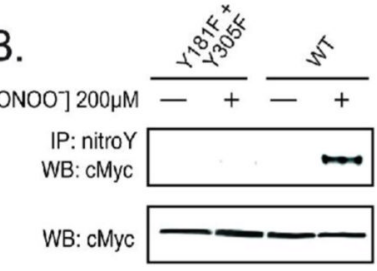

D.

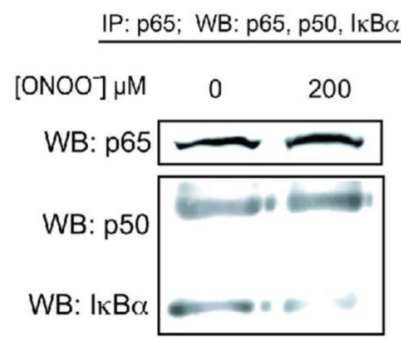

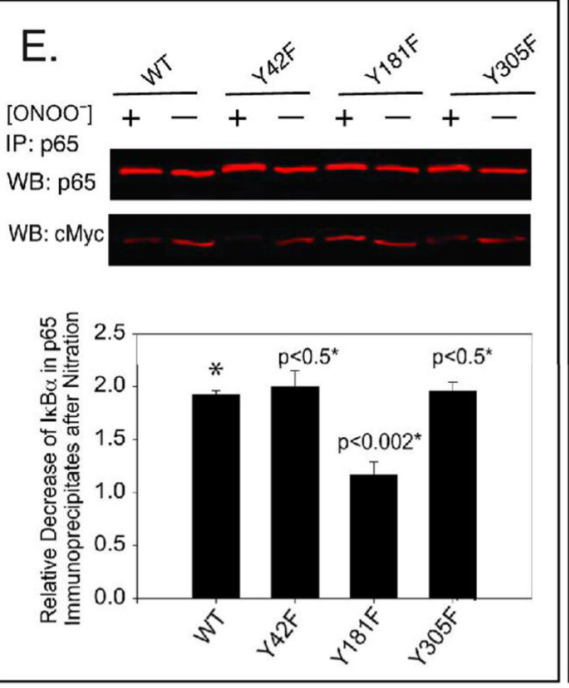

F.

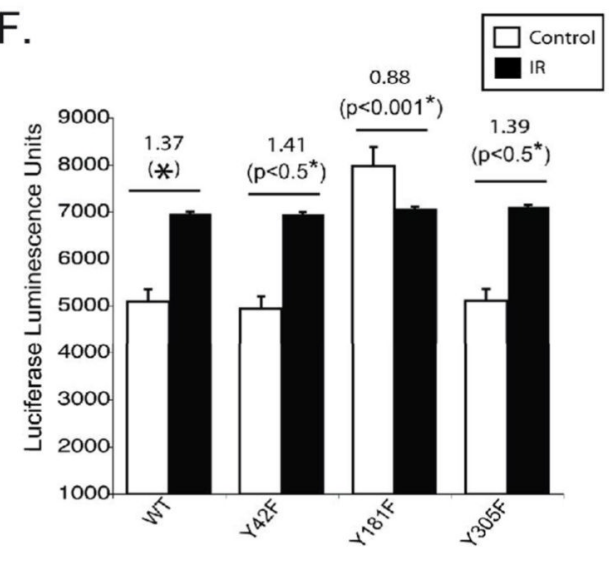

Numbers on the top - the relative reporter activity (irradiated/non-irradiated).

$177 \times 204 \mathrm{~mm}(300 \times 300$ DPI $)$

Figure 4.

Tyrosine-nitration of $\mathrm{I} \kappa \mathrm{B} \alpha$ dissociates the $\mathrm{I} \kappa \mathrm{B} \alpha / \mathrm{NF}-\kappa \mathrm{B}$ complex. A. Cell lysates from $\mathrm{CHO}$ cells expressing I $\kappa \mathrm{B} \alpha$ wild type and different $\mathrm{Y} \rightarrow \mathrm{F}$ mutants were treated with $\mathrm{ONOO}^{-}$. Antinitro-tyrosine immunoprecipitates were analyzed by immunoblotting with anti-IкB $\alpha$. Cell lysates were probed with anti-I $\mathrm{B} \alpha$ to verify equal loading (lower panel). Control untransfected sample. B. Cell lysates from $\mathrm{CHO}$ cells expressing cMyc-tagged $\mathrm{I} \kappa \mathrm{B} \alpha$ wild type and double mutant $181 / 305 \mathrm{YY} \rightarrow \mathrm{FF}$ were treated with $\mathrm{ONOO}^{-}$. Anti-nitro-tyrosine immunoprecipitates were analyzed by immunoblotting with anti-cMyc. Cell lysates were probed with anti-cMyc to verify equal loading of cMyc-tagged I $\kappa \mathrm{B} \alpha$ (lower panel). C. p65 and $\mathrm{I} \kappa \mathrm{B} \alpha$ immunoprecipitates were obtained from $\mathrm{ONOO}^{-}$treated cell lysates as described in the 
text. Preliminary control experiments demonstrated that the amount of antibody used was sufficient to fully immunoprecipitate the target antigen. Samples from first (lanes 1,2,3) and second (lanes 4, 5, 6) immunoprecipitations were analyzed for p65 (upper panel) and IкB $\alpha$ (middle panel) by immunoblotting. The blots were probed simultaneously with anti-nitrotyrosine antibody (bottom panel). D. After $\mathrm{ONOO}^{-}$treatment, anti-p65 immunoprecipitates were analyzed for p50 and I $\kappa \mathrm{B} \alpha$. The loading control was p65 (upper panel). E. CHO-cells were transfected with plasmids encoding c-myc-tagged wild type and the $\mathrm{Y} \rightarrow \mathrm{F}$ mutants of I $\mathrm{K} \alpha$. Cell lysates prepared 24 hours after transfection were treated with $200 \mu \mathrm{M} \mathrm{ONOO}^{-}$. Anti-p65 immunoprecipitates were analyzed by Western blot for p65 and c-myc. The fluorogram from one of two experiments is shown. The fluorescence intensity readings from two different experiments were used to calculate the relative nitration-induced decrease of I $\kappa \mathrm{B} \alpha$ associated with p65 calculated as average intensity of I $\mathrm{B} \alpha$ normalized to the loading control (p65 intensity) of +/-standard deviation. * - The p values were determined by Student's t-test relative to wild type transfected cells. F. DNA-binding activity of NF- $\mathrm{kB}$ was estimated

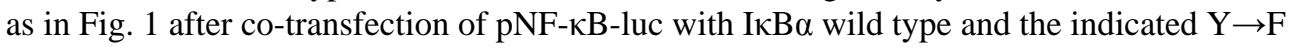
mutants. The increase in activity after IR was normalized relative to cells co-transfected with pNF- $\kappa B$-luc and empty vector. Data are means \pm SD for quadruplicate samples and representative for experiments performed in triplicate. ${ }^{*}-$ The $\mathrm{p}$ values were determined by Student's t-test relative to the wild type transfected cells. 

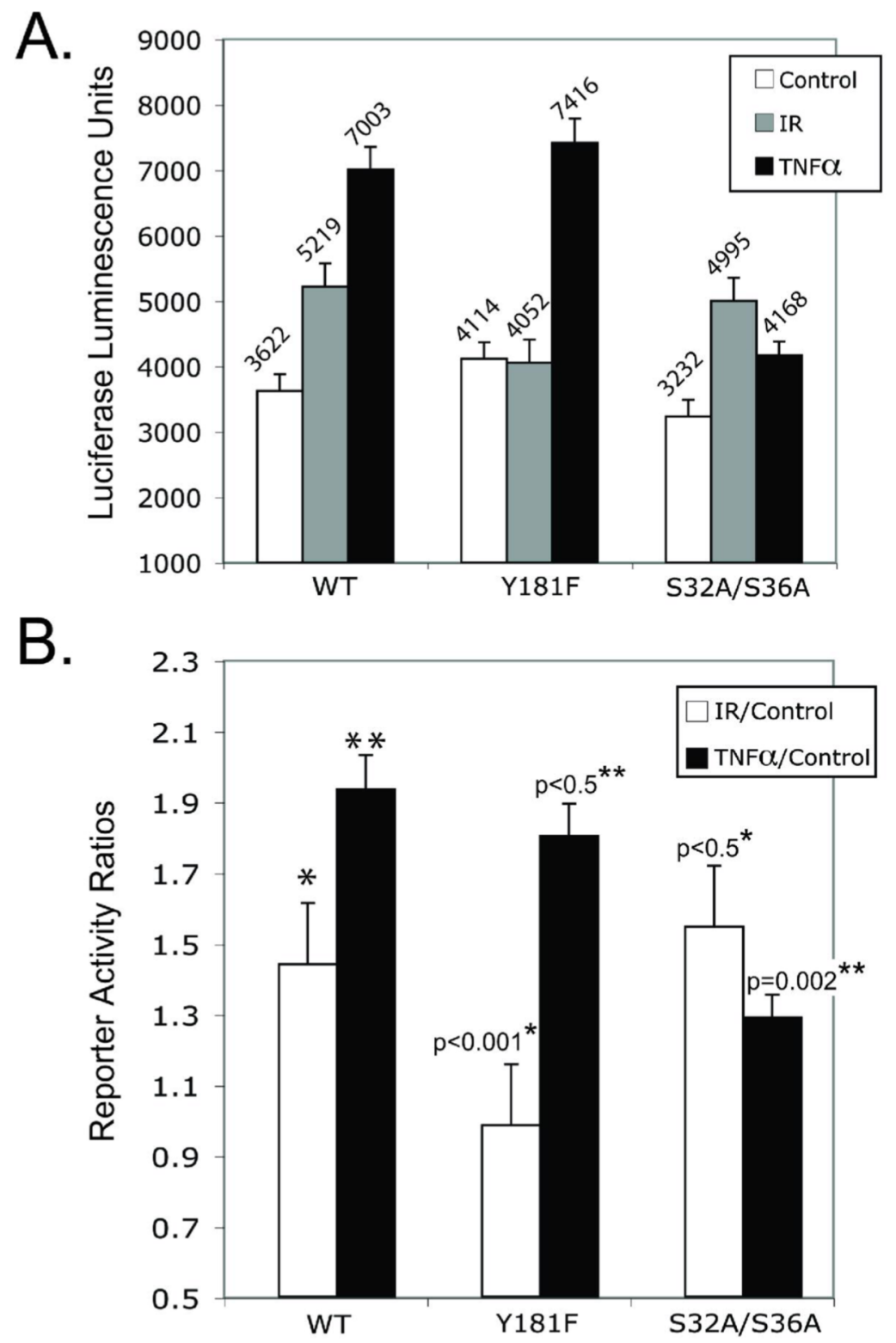

$82 \times 120 \mathrm{~mm}(600 \times 600 \mathrm{DPI})$

Figure 5.

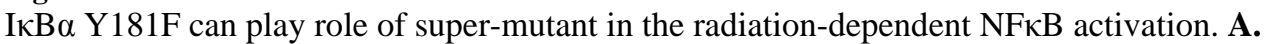

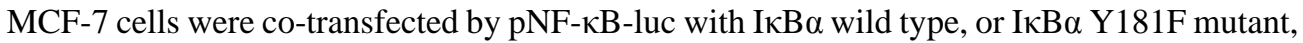
or I $\mathrm{BB} \alpha \mathrm{S} 32 \mathrm{~A} / \mathrm{S} 36 \mathrm{~A}$ mutant. Cells were radiated (5 Gy) or incubated with TNF- $\alpha$ (10nM) 48 $\mathrm{h}$ after transfection and luciferase activity was measured in cell lysates $24 \mathrm{~h}$ later. B. Absolute luminescence values are provided in Fig.5A converted into reporter activity ratios of treated versus non-treated cells. Data are means $\pm \mathrm{SD}$ for quadruplicate samples and representative for experiments performed in triplicate. *,** The p values were determined by Student's t-test relative to the I $\mathrm{K} B \alpha$ wild type transfected cells for radiated/non-radiated ratios. $* *-$ The $\mathrm{p}$ values 
were determined by Student's t-test relative to the I $\kappa \mathrm{B} \alpha$ wild type transfected cells for TNF$\alpha$-treated/non-treated ratios. 

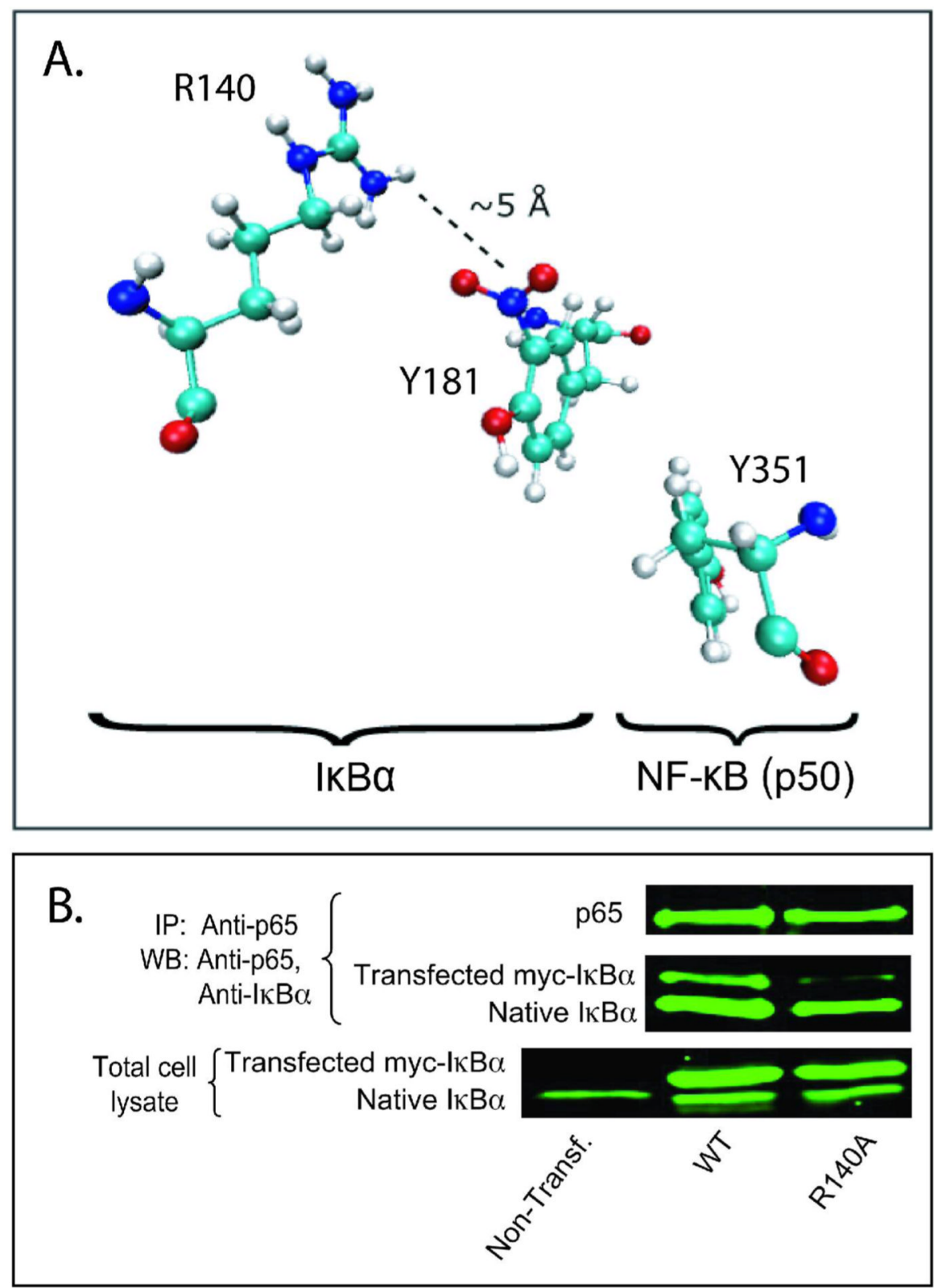

$82 \times 114 \mathrm{~mm}(600 \times 600 \mathrm{DPI})$

Figure 6.

The spatial relationship between $\mathrm{NO}_{2}$ group of $\mathrm{Y} 181$ and $\mathrm{R} 140$ of $\mathrm{I} \kappa \mathrm{B} \alpha$. A. R140, an inherently electropositive residue, buffers the electronegative charge of nitrated Y181 via long-range electrostatic interactions as evidenced by out-of-plane rotation of the $\mathrm{NO}_{2}$ group. Optimized structure of nitrated tyrosine indicates that the most optimal structure is when the $\mathrm{NO}_{2}$ group is in the plane of the phenol ring. B. R140 of I $\mathrm{B} \alpha$ is responsible for stability of $\mathrm{NF}-\kappa \mathrm{B} / \mathrm{I} \kappa \mathrm{B} \alpha$ complex. CHO cells were transfected by wild type and R140A mutant myc-IкB $\alpha$. Cell lysates were prepared 24 hours after transfection and immunoprecipitated by anti-p65 antibodies. Immunoprecipitates were analyzed by blotting with anti-p65 and anti-I $\kappa \mathrm{B} \alpha$ antibodies. Equal amount of cell lysates were used as a transfection control (bottom panel). 
Table 1

HINT score calculations (Y181 before and after nitration with p50 and IкB $\alpha$ ).

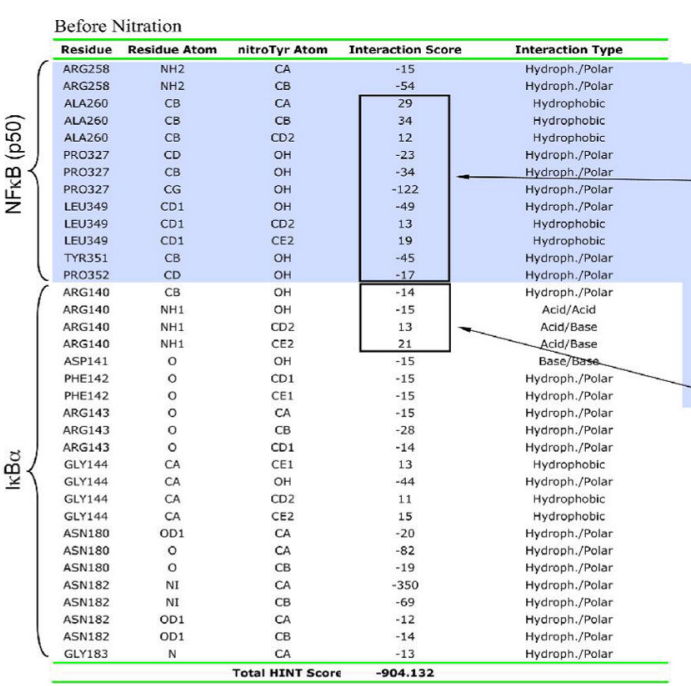

After Nitration

Residue Residue Atom nitroTyr Atom Interaction Score Interaction Type

Summary of HINT Scores - ІкBa Y181 with:

\begin{tabular}{|ccc|}
\hline & Before Nitration & After Nitration \\
\hline $\mathrm{p} 50$ & -218 & -1970 \\
$\mathrm{I} \mathrm{KBa}$ & -686 & +187 \\
\hline
\end{tabular}

\begin{tabular}{|c|c|c|c|c|}
\hline & & & & \\
\hline PRO327 & $\mathrm{CD}$ & $\mathrm{OH}$ & & Hycroph./Polar \\
\hline & $C D$ & & & \\
\hline & $C D$ & & & \\
\hline & CB & $\mathrm{OH}$ & -33 & Hydroph./Polar \\
\hline & CB & NE2 & & Hydraphobic \\
\hline & $\mathrm{CB}$ & ON1 & & Hydroph.JPolar \\
\hline & CB & ON2 & -106 & Hycroph./Polar \\
\hline PRO327 & CG & & & Hydroph./Polar \\
\hline & CG & NE2 & 57 & Hydrophobic \\
\hline & cG & ON1 & -93 & Hydroph./Polar \\
\hline PRO327 & cG & ON2 & -424 & Hydroph./Polar \\
\hline LEV349 & CB & ON1 & -33 & Hydroph./Polar \\
\hline LEU349 & CG & oN1 & -15 & Hycroph./Polar \\
\hline $\begin{array}{l}\text { LEV349 } \\
\text { LEV349 }\end{array}$ & CD1 & $\mathrm{OH}$ & -47 & Hycroph./Polar \\
\hline $\begin{array}{l}\text { LUE349 } \\
\text { LEU349 }\end{array}$ & $\begin{array}{l}C D 1 \\
C D 1\end{array}$ & $\begin{array}{l}\mathrm{CD} 2 \\
\text { NE2 }\end{array}$ & 14 & Hydrophobic \\
\hline LEU349 & $\mathrm{CD} 1$ & $\begin{array}{l}\text { NE2 } \\
\text { ON1 }\end{array}$ & $\begin{array}{c}142 \\
-853\end{array}$ & $\begin{array}{l}\text { Hydrophobic } \\
\text { Hycroph. Polar }\end{array}$ \\
\hline LEU349 & $\mathrm{CD} 1$ & ON2 & -158 & Hycroph Polar \\
\hline LEU349 & $\mathrm{CD} 2$ & NE2 & 23 & Hydrophobic \\
\hline LeOSA2 & $\mathrm{CD} 2$ & ON1 & -190 & Hycroph./Polar \\
\hline ARG140 & NHE & NE2 & 228 & Hydrogen Bond \\
\hline ARG140 & NH1 & ON1 & 995 & Hydrogen Bond \\
\hline ARG140 & NH1 & on:- & 261 & Hydrogen Bond \\
\hline ARG140 & NH2 & NE2 & 16 & Acid/Base \\
\hline ARG140 & $\mathrm{NH} 2$ & ON1 & 113 & Acid/Bose \\
\hline ARG140 & $\mathrm{NH2}$ & ON2 & 31 & Acid/8ase \\
\hline ASP141 & 0 & $\mathrm{OH}$ & -12 & Base/Base \\
\hline $\begin{array}{l}\text { PHE142 } \\
\text { PHE142 }\end{array}$ & $\circ$ & CD1 & -15 & Hydroph.,Polar \\
\hline $\begin{array}{ll}\text { ARG142 } \\
\text { ARG143 }\end{array}$ & $\begin{array}{l}0 \\
0\end{array}$ & $\begin{array}{l}\text { CE1 } \\
\text { CA }\end{array}$ & $\begin{array}{l}-15 \\
-15\end{array}$ & $\begin{array}{l}\text { Hydroph.,Polar } \\
\text { Hydroph. PPolar }\end{array}$ \\
\hline ARG143 & o & $\mathrm{CB}$ & $\begin{array}{l}-15 \\
-28\end{array}$ & $\begin{array}{l}\text { Hydroph.,Polar } \\
\text { Hydroph.polar }\end{array}$ \\
\hline ARG143 & 0 & $C D 1$ & -14 & Hydroph./Polar \\
\hline GLY144 & CA & CE1 & 13 & Hydrophobic \\
\hline GLY144 & $C A$ & $\mathrm{OH}$ & -41 & Hydroph./Polar \\
\hline GLY144 & $c a$ & $\mathrm{CD} 2$ & 12 & Hydrophobic \\
\hline GLYY144 & CA & NE2 & 32 & Hydrophobic \\
\hline GLYY144 & $c A$ & ON1 & -40 & Hycroph/Polar \\
\hline GLYY144 & CA & ON2 & -34 & Hydroph.JPolar \\
\hline GLY144 & $\circ$ & NE2 & -33 & Base/Base \\
\hline GLY144 & 0 & ON1 & -76 & Bosc/Base \\
\hline 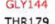 & 0 & ONA2 & -48 & Base/Base \\
\hline $\begin{array}{l}\text { THR179 } \\
\text { TH12179 }\end{array}$ & 0 & 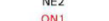 & -21 & Base/Base \\
\hline THR179 & 0 & 2 & -20 & Basépase \\
\hline ASN182 & NI & $C A$ & -350 & Hydroph./Polar \\
\hline ASN182 & NI & $\mathrm{CB}$ & -69 & Hycroph./Polar \\
\hline & & & -1783 & \\
\hline
\end{tabular}

$177 \times 126 \mathrm{~mm}(400 \times 400 \mathrm{DPI})$ 